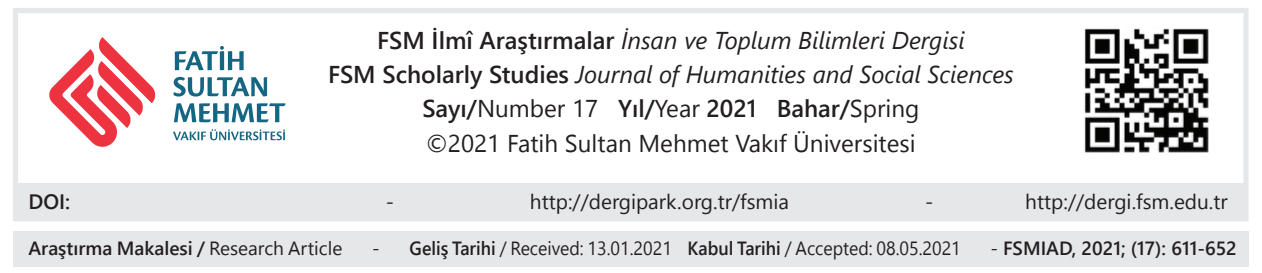

\title{
Osmanlı Hâşiye Kültürüne Bir Katkı: Koca Mehmed Râgıb Paşa ve Beydâvî Hâşiyesi ${ }^{*}$

\author{
Melek Mollaibrahimoğlu** \\ Hidayet Aydar***
}

\section{$\ddot{O} z$}

Bu çalışmada devrinin vakanüvisi Vasıf Efendi’nin, “İnsan-1 kâmil denilmeğe sezâ, sadru'l-vüzerâ elkabına revâ" diye nitelendirdiği, ünlü bir devlet adamı olduğu kadar edebî ve ilmî yeteneğiyle de maruf ve meşhur olan Koca Mehmed Râgıb Paşa’nın (1698/991763), Beydâvî'nin Envâru't-tenzîl ve esrâru't-te'vîl isimli tefsirine yazdığı hâşiye irdelenmektedir. Bu amaçla ilk olarak, muhaşşînin hayatından icmâlî olarak bahsedilmektedir. Daha sonra mahtût bir eser olan bu Hâşiye hakkında şekil ve üslûp bakımından bazı bilgiler verilmektedir. Çalışmada eser, metot ve muhteva yönünden de değerlendirilmektedir. $\mathrm{Bu}$ çerçevede hâşiyede rivâyet ve dirâyet yöntemlerinin nasıl işlendiği somut örnekler üzerinden tespit edilmeye çalışılmaktadır. Hâşiyenin esbab-ı nüzule yaklaşımı, israiliyat konusundaki tavrı, i'câzu'l-Kur'ân hakkındaki beyanları, kıraatlere yönelik açıklamaları,

* Bu çalışma 2019 yılında Melek Mollaibrahimoğlu tarafından hazırlanıp sunulan Koca Râgıb Mehmed Paşa ve Hâşiye 'Alâ Tefsiri'l-Kâdî el-Beydâvî Adlı Eserin Tahlîli başlıklı yüksek lisans tezi esas alınarak hazırlanmıştır.

** Öğr. Gör., Bingöl Üniversitesi İlahiyat Fakültesi Temel İslam Bilimleri Bölümü Kur'an-1 Kerim Okuma ve Kırâat İlmi Ana Bilim Dal1, Bingöl/Türkiye, mmolla@bingol.edu.tr, orcid. org/0000-0003-4094-1836

*** Prof. Dr., İstanbul Üniversitesi İlahiyat Fakültesi Temel İslâm Bilimleri Bölümü Tefsir Ana Bilim Dalı, İstanbul/Türkiye, hidayet@istanbul.edu.tr, orcid.org/0000-0002-7563-5073 
sarf ve nahve dair izahları da işlenmektedir. Mühaşşi Koca Ragıb'ın yapmış olduğu fikhî ve kelâmî açıklamalar da bahse konu edilmektedir. Hâşiyede yararlanılan kaynaklar da belirtilmektedir. Ayrıca bu makalede, eserin Osmanlının hâşiye kültürü içinde ne tür bir kıymeti hâiz olduğu, alana nasıl bir katkı sağladığı ve yine birçok başarılı edebî ve tarihî eserler ile adından sıklıkla söz ettiren Râgıb Paşa'nın, İslâmî ilimlerde de aynı derecede behresi olup-olmadığı şeklindeki birtakım suallere cevaplar aranmaktadır.

Anahtar Kelimeler: Tefsir, Hâşiye, Beydâvî, Râgıb Paşa, İslâmî ilimler.

\section{A Contribution to the Ottoman Hāshiya Culture: Koca Mehmed Rāgib Pasha and His Baydāwī Hāshiya}

\section{Abstract}

In this study, the annotation (hāshiya) of Koca Mehmed Rāgib Pasha (d.1698/991763) to Baydāwī's tafsīr book called Anwāru't-tanzîl wa Asrāru’t -ta'wīl is analyzed. Vasıf Efendi -who was a chronicler in his time- defined Koca Mehmed Rāgib Pasha -who was literary scholarly talented and the famous statesman- as "İnsan-1 kâmil denilmeye sezâ, sadru'l-vüzerâ elkabına revâ." For this purpose, initially, the life of the annotator (muhashshi) is mentioned generally. And then information about style and genre of the annotation which is a written work is given. Also in this study the book is evaluated in terms of method and content. Within this scope, how riwāyat and dirāyat methods were used in this annotation is tried to be detected with concrete examples. The annotation's approaches to the reasons of the revelation (asbab al-nuzûl), the attitude about isrāiliyyāt, the statements about I'cāzu'l-Qur'ān, the explanations on qiraāt, the explications related to sarf and nahw are handled. The fiqhī and kalāmī explanations which Koca Rāgib Pasha made are mentioned too. The used references in the annotation are given. In this article, the answers to the questions as how important the annotation culture is in the Ottoman, how they contributed to this field and whether Koca Rāgib Pasha who is cited in the literary and historical works often is successful as far as in the Islamic Sciences are searched.

Keywords: Tafseer, Hāshiya, Baydāwī, Rāgib Pasha, Islamic Sciences. 


\section{Giriş}

Vahy-i ilâhî'yi anlama ve yorumlama çabaları, Kur'ân'ın nüzûlünden itibaren dinamik bir şekilde süregelen ve anlayan özneler var oldukça da inkıtasından söz edilmesi mümkün olmayan fikrî bir faaliyetin tezahürüdür. Nitekim telif edilen ve günümüze dek ulaşan yüzlerce tefsir eserleri bu faaliyetin sürekliliğini açıkça yansitmaktadır. Esasen insanın birtakım algilama ve akletme melekeleriyle donanmış olarak yaratılması, fitratında bilgiye karşı olan merak duygusu ve yine mümeyyiz vasfı olan öğrenme arzusu/kabiliyeti böyle bir düşünme ediminin sürekliliğini gerektirecektir.

İslam tarihi boyunca ifa edilegelen bu faaliyetler nazar-1 itibara alındığında gerek muhtevâ, gerek metodoloji, gerekse mezhebi ve meşrebi doğrultusunda kişilerin yapmış olduğu bu çalışmaların farklı nitelikler arz ettikleri tarihî ve sosyal bir realitedir. İlâhî kelamın/hitabın anlaşılmasına dair yapılan bu farklı çalışmalardan birisi de Kur'ân'ın nüzûlünden yaklaşık altı asır sonra tebellür eden ve makalemizin de konusunu teşkil eden hâşiye türü eserlerdir. Bu tarz eserler, daha çok Zemahşerî'nin (v. 538/1144) ölümsüz eseri el-Keşşaf üzerine yazılan hâşiyelerle birlikte yaygınlaşmış, Beydâvî'nin (v. 685/1286) Envaru't-tenzîl'i üzerine yazılan hâşiyelerle zirveye ulaşmış, böylece bu alanda muazzam bir hâşiye literatürü oluşmuştur.

Bu çalışmada, 18. yüzyılın önemli idarî ve siyasî simalarından ve ender şahsiyetlerinden biri olan Koca Mehmed Râgıb Paşa'nın Mısır'a vali olarak atandı̆̆ı 1744 tarihi ile Rakka vilayetinde görevli olarak bulunduğu 1755 yılları arasında kaleme aldığ 1 Hâşiye 'alâ tefsiri'l-Kâdî el-Beydâvî adlı eseri muhtevâ ve metodoloji yönüyle ana hatlarıyla ${ }^{1}$ incelenecektir.

Bu makale ile ayrıca Allah'ın Kitabı'nın doğru anlaşılması/yorumlanması yönünde azamî gayret sarf eden Osmanlı âlimlerinin ortaya koyduğu ilmî ve kültürel mirasin yetkin bir envanterinin tahric ve tespit edilmesine mütevazı bir katk1 oluşturması amaçlanmaktadır. Esasen bu husus bu kültürün varisleri olarak bizlerin omzuna, bu birikimin aktarılması ve sağl1klı bir şekilde değerlendirilmesi yönünde bir vazife yüklemektedir.

Râgıp Paşa ve eserleriyle ilgili tez, makale, bildiri gibi muhtelif çalışmalar, edebî ve tarihî araştırmalar yapılmıştır. ${ }^{2}$ Bunların bir kısmı onun şairliği ve şiir-

1 Geniş bilgi için bk. Melek Mollaibrahimoğlu, "Koca Râgıb Mehmed Paşa ve Hâşiye 'Alâ Tefsiri'l-Kâdî el-Beydâvî Adlı Eserin Tahlîli”, (Yayımlanmamış Yüksek Lisans Tezi), İstanbul Üniversitesi İlahiyat Fakültesi, İstanbul, 2019, s. 39-160.

2 Bk. Bilge Karga Göllü, "Koca Râgıp Paşa Üzerine Bir Kaynakça Denemesi”, Çukurova Üniversitesi Sosyal Bilimler Enstitüsü Dergisi 25/4, 2016, s. 137-146. 
lerinin yer aldığ 1 eserleriyle ilgiliyken, ${ }^{3}$ bir kısmı resmî görevlerini ifa ederken yazdığı münşeât ve telhisâtlarla ilgilidir. ${ }^{4}$ Ancak Râgıb Paşa'nın tefsirciliği ve burada sözünü edeceğimiz hâşiyesi üzerine yapılmış herhangi bir çalışmaya rastlamadık. Daha da ötesi hâşiyeler üzerine yazılmış kitaplarda ve Osmanlı'da tefsir hâşiyeciliği konusunda yazılmış birçok eserde, böyle bir hâşiyeden bahsedildiğini dahi görmedik. Nitekim hâşiyeler üzerine 3 ciltlik kapsamlı bir eser vücuda getirmiş olan el-Habeşî, eserinin Envâru 't-tenzîl ve esrâru't-te'vîl tefsiri üzerine yazılmış olan hâşiyeler kısmında çok sayıda hâşiyeden muhaşşinin ismini açıkça tasrih ederek bahsettiği halde ${ }^{5}$ sadece bir yerde burada üzerinde durduğumuz kitap hakkında (حاثية على تفسير البيضاوي خ راغب باشا 149-11) şeklinde bir bilgi vermiştir ${ }^{6} \mathrm{ki}$, bununla burada üzerinde durduğumuz esere mi işarete diyor, yoksa Ragıb Paşa Kütüphanesindeki başka yazma bir nüshaya mı dikkat çekiyor, belli değildir. Burada üzerinde durduğumuz esere işaret edildiğini kabul etsek bile, kitapta hâşiyeyle ilgili bundan başka bilgi yoktur ki bunun da çok yetersiz bir malumat olduğu aşikârdır. Şükrü Maden de hem genel olarak hem de Osman11 âlimlerince Beydâvî tefsiri üzerine yazılmış tam olanlar ile bir kısmı üzerine yapılmış eksik olanlar dahil çok sayıda hâşiyeden bahsettiği halde tam bir hâşiye olan Ragıb Paşa'nın Hâşiyesiyle ilgili herhangi bir bilgi vermemektedir.? Diğer bazı çalışmalarda da Ragıb Paşa ve eseriyle ilgili bir bilgi bulamadık. ${ }^{8}$ Daha ilgin-

3 Bk. Hüseyin Yorulmaz, "Koca Râgıb Paşa Dîvânı (Araştırma ve Metin)”, (Yayımlanmamış Yüksek Lisans Tezi), İstanbul Üniversitesi, İstanbul, 1989, s. 30-166; Yasin Dursun, "Koca Râgıb Paşa'nın Arûz Risalesi Adlı Eserinin Tahkik ve Tahlili”, (Yayımlanmamış Yüksek Lisans Tezi), İstanbul Üniversitesi, İstanbul, 2014, s. 32-58.

4 Bk. H. Abdulkadir Özel, “Koca Râgıb Mehmed Paşa'nın Münş’eât ve Telhîsâtı”, (Yayımlanmamış Yüksek Lisans Tezi), Mimar Sinan Güzel Sanatlar Üniversitesi, İstanbul, 2014, s. XXII-LXI.

5 Bk. Abdullah Muhammed el-Habeşî, Câmiu'ş-şurûh ve'l-hevâşî mu'cemun şâmilun li kutubi 'l-meşrûha fi 't-turâsi'l-İslâmî ve beyânu şurûhiâ, 1, Ebuzabî, el-Mecmau's-sakâfî, 2004, s. 310-343.

6 Bk. el-Habeşî, Câmiu'ş-şurûh ve'l-hevâş̂ิ, 1, s. 332.

7 Bk. Şükrü Maden, “Tefsirde Şerh Haşiye ve Ta'lika Lüteratürü”, Tarih Kültür ve Sanat Araştırmalarl Dergisi, 3/1, 2014, s. 193-211 Ayrıca bk. a.mlf., "Osmanlılar'da el-Keşşâf ve Envâru’t-Tenzîl Hâşiyeleri”, Türkiye Araştırmaları Literatür Dergisi, 9/18, 2011, s. 241-273; a.mlf. Tefsirde Hâş̧iye Geleneği ve Şeyhzâde’nin Envâru 't-Tenzîl Hâşiyesi, İstanbul, İSAM Yayınları, 2015, s. 31-116.

8 Bk. Muhammed Abay, “Osmanlı Döneminde Tefsir Haşiyeleri”, Başlangıçtan Günümüze Türklerin Kur'an Tefsirine Hizmetleri-Tebliğler ve Müzakereler-, İstanbul, Ensar Neşriyat, 2012, s. 167-194; Mesut Kaya, “İslam İlimler Tarihinde Muhâkemât Geleneği: Tefsir Hâşiyeleri Merkezli Bir Deneme”, İslam Araştırtmaları Dergisi, 33, 2015, s. 29-34; Hakan Uğur, "Konya Yusufağa ve Bölge Yama Eserler Kütüphanesi'ndeki Başlıca Beydâvî Hâşiyeleri”, Osmanlı Toplumunda Kur'an Kültürü ve Tefsir Çalışmaları 1, ed. Bilal Gökkır-Necdet Yılmaz-Necmettin Gökkır-Ömer Kara-Muhammed Abay-Mustafa Karagöz, İstanbul, İlim Yayma Vakfi, 2011, s. 427-440. 
ci hayatı hakkında bilgi veren eserlerde ve tezlerde de hâş̧iyesine dair bir bilgiye tesadüf etmedik. ${ }^{9}$

Ancak araştırmalarımız neticesinde edindiğimiz bilgiye göre Abdulkadir Özel, tezinde Ragıb Paşa'nın Kâdî Beydâvî tefsiri üzerine yazmış olduğu bir hâşiyesinin olduğuna temas etmektedir. ${ }^{10}$ Nüshayı ilk olarak tespit eden ve onu eserleri arasında zikreden kişi ise, Râgıb Paşa Kütüphanesi fihristini hazırlayan Mahmud Seyyid ed-Duğeym'dir. ${ }^{11}$ Bundan başka bir bilgiye rastlamadık. Bu konuda yapılmış ilk ve tek akademik çalışma olarak Melek Mollaibrahimoğlu'nun tezini ${ }^{12}$ görmekteyiz. Mollaibrahimoğlu'nun tezinden istifadeyle oluşturulan bu makale de görebildiğimiz kadarıyla bu alanda yazılmış ilk makale niteliğindedir. Mollaibrahimoğlu'nun çalışması tez olarak, bu makalemiz de makale olarak bilhassa bu yönü itibariyle özgünlük arz etmektedir. Biz bu çalışmaların, ileride yapılacak çalışmalara kaynaklık teşkil etmesini umuyoruz. Makaled başta Mollaibrahimoğlu'nun tezi olmak üzere Koca Ragıb Mehmet Paşa üzerine yapılmış çalışmalardan istifade edildiği gibi ayrıca şekil bakımından daha sonra kitap olarak basılmış olan Şükrü Maden'in ${ }^{13}$ tezi ile Ersin Çelik'in ${ }^{14}$ tezleri gibi hâşiyeler üzerine yapılmış bazı çalışmalardan da yararlanılmıştır.

9 Bk. Yorulmaz, Koca Râgıb Paşa Dîvânı (Araştırma ve Metin), s. 43-51; Mesut Aydıner, "Dönemin Kaynakları ve Arşiv Belgelerine Göre Koca Râgıb Mehmed Paşa'ya Dair Bir Portre”, Çukurova Üniversitesi Sosyal Bilimler Enstitüsü Dergisi, 25/4, 2016, s. 25-27; Dursun, Koca Râgıb Paşa'nın Arûz Risalesi Adlı Eserinin Tahkik ve Tahlili, s. 48-50.

10 Bu çalışmada Râgıb Paşa'nın bir mektubunda kullanmış olduğu imzadan yola çıkılarak kendisinin Beydâvî tefsirine tashih ve tahşiyede bulunduğu ifade edilmektedir. Bahsedilen bu imzayla ilgili ise şu cümleler kaydedilmiştir: "Sadr-1 esbâk merhum Râgıb Paşa hazretleri tashih ü tahşiye buyurdukları Tefsir-i Beydâvî'nün hitamına tahrîr buyurdukları imzâdur” başlıklı takriz. Bk. Özel, Koca Râgıb Mehmed Paşa'nın Munşe'ât ve Telhîsâtı, s. 28.

11 Râgıb Paşa Kütüphanesi fihristini on cilt halinde hazırlayan Mahmud ed-Duğeym, Râgıb Paşa'nın hayatını kaleme aldığı ilk cildinde bu hâş̧iyenin mevcudiyetini nüshasıyla ispat etmektedir. O, kendisinden önce hiçbir müfehrisin bu eserden bahsetmediğini ve kendisinin de ancak bu çalışma esnasında eserin bilgisine/nüshasına muttali olduğunu dile getirmektedir. Bk. Mahmud es-Seyyid ed-Duğeym, Fihrisu'l-mahtûtâti'l-Arabiyye ve 't-Turkiyye ve'l-Fârisyye fi mektebeti Râgıb Paşa, 1, Cidde, Sekîfetu's-safa el-ilmiyye, 1437/2016, s. 146-147.

12 Bk. Melek Mollaibrahimoğlu, "Koca Râgıb Mehmed Paşa ve Hâşiye 'Alâ Tefsiri'l-Kâdî el-Beydâvî Adlı Eserin Tahlîli”, (Yayımlanmamış Yüksek Lisans Tezi), İstanbul Üniversitesi İlahiyat Fakültesi, İstanbul, 2019.

13 “Tefsirde Hâşiye Geleneği ve Hâşiyetu Muhyiddin Şeyhzâde 'Alâ Tefsiri'l-Kâdî el-Beyzâvî Örneği”, (Yayımlanmamış Doktora Tezi), Marmara Üniversitesi, İstanbul, 2013.

14 “Şeyhu'l-İslam Sa'dî Çelebî ve el-Fevâidu'l-Behiyye: Hâşiye Alâ Tefsiri'l-Beyzâvî Adlı Eserinin Tahlili", (Yayımlanmamış Yüksek Lisans Tezi), Recep Tayyip Erdoğan Üniversitesi, Rize, 2015. 


\section{Râgıb Paşa'nın Hayatı}

Çok renkli ve çok yönlü bir zat olan Ragıb Paşa, âlimliğinden ziyade siyasî ve bürokratik kişiliğiyle temayüz etmiştir. $\mathrm{O}$ yüzden biz de öncelikle bu yönü üzerinde duracağız.

\subsection{Siyasî ve İdârî Hayatı}

Birçok eserde Râgıb Paşa'nın İstanbul'da 1110/1698-99 senesinde dünyaya geldiğ $1^{15}$ ve asıl adının Mehmed olduğu bildirilmektedir. ${ }^{16}$ Kaleme aldığ 1 birçok eserinde kullandığı "Râgıb" mahlasına daha küçük yaşından itibaren ilme, bilgiye, kitaplara ve edebiyata olan rağbetinden dolayı müstahak olmuş, akranları arasında "Ragıb" diye çağrılmıştır. ${ }^{17}$ Esasen "râgıb" da "rağbet eden, ilgi ve alaka gösteren" anlamındadır. Bu mahlasını şiirlerinde de kullanmıştır. Devlet bürokrasisinde üst düzey görevler alması itibariyle "Paşa", -zannımızca- bu görevlerde

15 Bu konuda Erhan Afyoncu şu bilgiyi kaydetmektedir: "Birçok eserde Paşa'nın 1110'da doğduğu zikredilir. Ancak Mehmed Râgıb'a 24 Safer 1142 (18 Eylül 1729)'de defter-i hakanî kâtiplik görevi tevcih olunurken tahminen otuz beş yaşında olduğu belirtilmektedir. Eğer bu tarihte yaşı tam otuz beş ise doğum tarihi 1107 (1695-1696) olacaktır. (Bk. Tapu Kadastro Genel Müdürlüğü, Kuyud-i Kadime Arşivi (= TKA), Tımar Ruznamçe Defteri (=TRD), nr. 813, 71'den naklen Erhan Afyoncu, “Kalemden Kılıca: Koca Râgıb Paşa’nın Osmanlı Bürokrasisinde Yükselişi”, Journal of Turkish Studies Türklük Bilgileri Araştırtmaları Şinasi Tekin Hatıra Sayısı I, haz. Yücel Dağl1-Yorgos Dedes-Selim S. Kuru, Boston, Harvard Üniversitesi, 2007, s. 11, dipnot 1.

16 Bk. Bursalı Mehmed Tahir, Osmanlı Müellifleri, 2, haz. Yekta Saraç, Ankara, Türkiye Bilimler Akademisi, 2016, s. 616-618; Ebû Gays Muhammed Hayruddîn b. Mahmud b. Muhammed Ali ez-Ziriklî, el-A'lâm kâmûsu terâcimi eşheri'r-ricâli ve'n-nîsâi mine 'l-arabî ve'l-musta'rabîn ve'l-musteşrikîn, 6, Beyrut, Dâru'l-ilim li'l-melâyîn, 2002, s. 123; Muhammed b. Murad el-Huseynî, Silku'd-durer fí a 'yâni'l-karni s-sânî 'aşer, 1-2, 3. bs., Beyrut, Dâru'l-beşâiri'l-İslamiyye-Dâru İbn Hazm, 1988, s. 85, 174, 259; s. 61, 184; Mesut Aydıner, "Koca Râgıb Mehmed Paşa- Hayatı ve Dönemi: 1699-1763”, (Yayımlanmamış Doktora Tezi), Mimar Sinan Güzel Sanatlar Üniversitesi, İstanbul, 2005, s. 12; a.mlf., "Râgıb Paşa", Türkiye Diyanet Vakfi İslam Ansiklopedisi DİA, 34, İstanbul, Türkiye Diyanet Vakfı Yayınları, 2007, s. 403; ed-Duğeym, Fihrisu'l-mahtûtât, 1, s. 141; Yorulmaz, Koca Râgıb Paşa Dîvânı (Araştırma ve Metin), 2-28; Niyazi Akşit-Ferruh Sanır, "Koca Ragıp Paşa”, Genel Bilgi Ansiklopedisi, İstanbul, Serhat Dağıtım, 1981, s. 851; Bekir Sttkı Baykal, "Râgıb Paşa", İslâm Ansiklopedisi, 9, İstanbul, Milli Eğitim Basımevi,1988, s. 594-596; Büyük Türk Klâsikleri, "Koca Râgıb Paşa", 6, İstanbul, Ötüken-Sögüt Yayınları, 1987, s. 379-386; Müjgan Cunbur, "Râgıb Paşa”, Türk Dünyası Edebiyatçıları Ansiklopedisi, 7, Ankara, AKM Yayıncılık, 2007, s. 268-269. Hakkında yapılmış çalışmalara için bk. Göllü, "Koca Râgıb Paşa Üzerine Bir Kaynakça Denemesi”, s. $137-146$.

17 Bk. Aydıner, "Râgıb Paşa”, 34, s. 403; Türk Edebiyatı İsimler Sözlü̆̆̈̈, "Beyhan Kesik, Koca Rağıb Paşa", erişim: 24.10.2020, http://teis.yesevi.edu.tr/madde-detay/koca-ragib-pasa. 
büyük başarılar elde etmesi itibariyle de "Koca" sıfatları kendisine verilmiş, böylece âlimimiz, Koca Ragıb Mehmed Paşa ismiyle bilinir olmuştur.

Râgıb Paşa, Defterhâne'de memur olan babasının yanında iyi bir eğitim almış, daha sonra muhtelif âlimlerin yanında eğitimini iyice sağlamlaştırarak kısa zamanda akranları arasında temayüz etmiş, ${ }^{18}$ bu sayede de Dîvân-1 Hümâyûn kâtipliğine getirilmiştir. ${ }^{19} \mathrm{Bu}$ görevi sürdürürken dönemin ilim ve kültürü için tek vasıta olan Arapça ve Farsçayı gayet iyi düzeyde öğrenmiştir. Farsça derslerini Hoca Salih Efendi'den almıştır. Ayrıca Yusuf Efendizâde'den sülüs ve nesih yazılarını meşk etmiştir. Onun, Asya dilleri gibi Avrupa dillerini de gayet iyi derecede öğrendiği belirtiliyor. ${ }^{20}$ Öte yandan dönemin ünlü şairlerinin Türkçe ve Farsça şiirlerini okumuş, onlara nazirler yazmıştır. Yukarıda belirtiğimiz gibi şiirlerinde Ragıb mahlasını kullanmıştır. Böylece hem dil, hem de edebiyat yönünden gayet iyi bir kişi olarak yetişmiştir. ${ }^{21}$

Râgıb Paşa ilmiye sınıfından ziyade kalemiye, seyfiye ve mülkiye sınıflarına mensuptur, ilmî kişiliğinden daha çok diplomat, siyasî ve askerî kişiliği ile öne çıkmıştır ve bu alanlarda tebarüz etmiştir. Bu yüzden ilmî hayatından ziyade memurluk hayatı hakkında bilgiler bulunmaktadır. Bununla birlikte aşağıda ilme olan merakına ve bu yöndeki gayretlerine de temas edeceğiz. Onun Farsça ve Arapçayı bilmesi ve yine imla ve kitabet ilmini haiz olması ona mesleğinde ilerleme yollarını açmış, daha 23-24 yaşındayken 1134/1722 yılında Osmanl1-İran savaşları esnasında fethedilen yerlerin tahrîri, yani bu bölgelerdeki nüfusun ve arazilerin yazım ve tescili ${ }^{22}$ için Revan Valisi Arifi Ahmet Paşa'nın maiyetine verilmiştir. Râgıb Paşa her ne kadar Ahmet Paşa'nın yanına

18 Bk. Mehmed Süreyya, Sicill-i Osmâni, 4, haz. Nuri Akbayar, İstanbul, Tarih Vakfı Yurt Yayınları, 1996, s. 1340; Muallim Naci, Osmanlı Şairleri, haz. Cemal Kurnaz, Ankara, Kültür Bakanlığı Yayınları, 1986, s. 238; İsmail Hikmet, Koca Ragıp Paşa ve Fitnat, İstanbul, Kanaat Kütüphanesi, 1933, s. 6; İsmail Hakkı Uzunçarş11, Osmanlı Tarihi, 6, Ankara, Türk Tarih Kurumu Yayınları, 1988, s. 345; Baykal, "Râgıb Paşa", 9, s. 594; Hüseyin Yorulmaz, Koca Ragıb Paşa, Ankara, Kültür Bakanlığı Yayınları, 1998, s. 1; Ayhan Buz, Sokullu'dan Damat Ferit'e Osmanl Sadrazamları, 2. bs., İstanbul, Neden Kitap, 2009, s. 249.

19 Baykal, "Râgıb Paşa", 9, s. 594.

20 A. De Lamartine, Sona Doğru (Türkiye Tarihi), 6, haz. M.R. Uzmen, Tercüman 1001 Temel Eser: 43, İstanbul, Kervan Kitapçılık, ts., s. 1580; Ömer Demirbağ, "Koca Râgıb Paşa ve Dîvân-1 Râgıb”, (Yayımlanmamış Doktora Tezi), Yüzüncü Y11 Üniversitesi, Van, 1999, s. 1-2.

21 İbrahim Mutlu, "Koca Ragıp Paşa Kütüphanesi 200 Yaşında”, Türk Kütüphaneciler Derneği Bülteni, 12/1-2, 1963, s. 2; Yorulmaz, Koca Râgıb Paşa Dîvânı (Araştırma ve Metin), 2-3; Aydıner, "Râgıb Paşa", 34, s. 403; Demirbağ, "Koca Râgıb Paşa ve Dîvân-ı Râgıb”, s. 18-57.

22 Bk. Mehmet Zeki Pakalın, Osmanlı Tarih Deyimleri ve Terimleri Sözlüğ̈̈, 3, İstanbul, Milli Eğitim Bakanlığ1, 1993, s. 176-177. 
tahrîr için gönderilmiş olsa da bir takım karışıklıklar sebebiyle bu görevini pek icra edememiş, bunun yerine birkaç önemli seraskerle ${ }^{23}$ (komutanla) tüm doğu cephesini dolaşmış ve böylelikle önemli tecrübeler kazanmıştır. Sonrasında kendisine 1728 tarihinde Revan Defterdarlığı ${ }^{24}$ gibi ilk ciddi pâye verilerek Osmanlı hiyerarşisinde vali ve kadıdan sonra gelen çok önemli bir makama -genç olmasına rağmen- getirilmiştir. Râgıb Paşa'nın buradaki defterdarlığı Revan'1n muhassile ${ }^{25}$ devredilmesinden dolayı pek uzun sürmemiş ve neticesinde İstanbul'a çağrılmıştır. İstanbul'a çağrılışından kısa bir süre sonra Patrona Halil İsyanıyla İstanbul'un karışması ve kaosun çıkması sebebiyle Râgıb Paşa, Bağdat Valisi Ahmed Paşa'nın yanına defterdar olarak gönderilmiştir. O sıralarda Osmanl1-İran devletleri arasında yapılan hemen tüm müzakerelerde murahhas yani delege olarak bulunmuştur. ${ }^{26}$

Bağdat'ın yedi ay süren zorlu kuşatmadan kurtarılmasındaki başarılarından dolay1 1148/1733'te İstanbul'a çağrılarak Maliye tezkireciliğiyle ${ }^{27}$ taltif edilmiştir. Bir müddet sonra da 1735 'te Erzurum seraskerliğine getirilen Ahmet Paşa'nın maiyetine ordu defterdarı ve reisulkuttâb ${ }^{28}$ vekili olarak verilmiştir. Aynı yı1ın temmuzunda tecrübeli biri olarak Nadir Şah'ın elçileriyle görüşmelerde bulunmak üzere tekrar İstanbul'a çağrılmıştır. ${ }^{29}$

Osmanlının gerileme devrinde reisiulkuttâb olarak görev başında olan Râgıb Paşa, ordunun içinde bulunduğu durumu göz önünde bulundurarak daima sulhtan yana tavır almış ve bunun tahakkuku için de ferâset ve basîretinin yansıması niteliğindeki özgün görüşlerini beyan etmekten çekinmemiştir. Reisliğe başladığ 1 ilk günlerinden itibaren görevinden azledinceye kadarki zamanda Osmanl1-İran arasında Nâdir Şah'ın Ca'ferî mezhebinin dört fikhî mezhebe paralel beşinci bir

23 Bk. Pakalın, Osmanlı Tarih Deyimleri ve Terimleri Sözlüğü, 3, İstanbul, Milli Eğitim Bakanl1ğ1, 1993, s. 376-377.

24 Defter, defterdar ve defterlik için bk. Pakalın, Osmanlı Tarih Deyimleri ve Terimleri Sözlüğü, 1, s. 411-418.

25 Osmanlı Devlet sisteminde muhassıl ve manaları için bk. Pakalın, Osmanlı Tarih Deyimleri ve Terimleri Sözlüğ̈̈, 2, s. 569-570.

26 Yorulmaz, Koca Râgıb Paşa Dîvânı (Araştırma ve Metin), s. 3-5; Baykal, "Râgıb Paşa", 9, s. 594-595; Mesut Aydıner, "Dönemin Kaynakları ve Arşiv Belgelerine Göre Koca Râgıb Mehmed Paşa'ya Dair Bir Portre”, Çukurova Üniversitesi Sosyal Bilimler Enstitüsü Dergisi, 25/4, 2016, s. 4-5.

27 Pakalın, Osmanlı Tarih Deyimleri ve Terimleri Sözlü̆̆̈̈, 3, s. 491-492.

28 Resisu'l-küttâb için bk. Pakalın, Osmanlı Tarih Deyimleri ve Terimleri Sözlüğü, 3, s. 25-27.

29 Yorulmaz, Koca Râgıb Paşa Dîvânı (Araştırma ve Metin), s. 6; Aydıner, "Dönemin Kaynakları ve Arşiv Belgelerine Göre Koca Râgıb Mehmed Paşa’ya Dair Bir Portre”, s. 5. 
mezhep olarak kabul edilmesi talebi yönünde seyreden mezhebî tartışmalarda Râgıb Paşa, bu teklifin kabul edilmesini ileri sürmüş ve bunun lafzî bir tasdikten öteye geçmeyeceğini de özellikle vurgulamıştır. ${ }^{30}$ Fakat bu durum, dönemin nüfuz sahibi olan Dârussaâde Ağası meşhur Hacı Beşir Ağa'yı rahatsız etmiş ve onun 1157/1744 yılında reislikten azledilip Misır valisi olarak İstanbul'dan uzaklaştırılmasıyla sonuçlanmıştır. ${ }^{31}$

Beş yıl kadar sürecek olan bu memuriyeti sırasında Râgıb Paşa, Mısır'daki birçok olumsuz koşullara rağmen yılların vermiş olduğu engin tecrübeyle görevine, eyaletin ahvalini teftiş, sslah ve tanzim etmek üzere Memlûk idarecilerinden güvendiği adamları işbaşına getirmekle başlamıştır. Yine o günlerde cereyan eden ve birçok tarım arazilerine zarar veren Nil nehri felaketinin üzerine İstanbul'a üst üste raporlar çekmek suretiyle bir an önce benzeri felaketleri önleyecek bir seddin inşasının başlamasını sağlamıştır. Bu vesileyle ortaya koyduğu görüşleri, sadrazam ve padişah tarafından takdir kazanmış; özverili çalışmalarıyla da o güne değin valilerden nefret eden Mısır halkının kalbinde apayrı bir yer edinmiştir. Hatta Mısır'ın ileri gelenleri, İstanbul'a mahzarlar ${ }^{32}$ irsal ederek Râgıb Paşa'nın görevinin uzatılmasını talep etmişlerdir. ${ }^{33}$

Mamafih Mısır'da Beşir Ağa destekli adamların çıkardıkları hâdiseler, Râgıb Paşa gibi daima sulhtan yana olan bir zatı bile canından bezdirmiştir. Nitekim Râgıb Paşa olası bir suikast endişesinden dolayı İstanbul'a bir mektup göndererek tayinini istemek durumunda kalmış ${ }^{34}$ ve oradaki yorgunluğunu, Kâhire'nin kahrını tarihe geçen şu dizeleriyle adeta ölümsüzleştirmiştir:

30 Şem ‘dânîzâde Süleyman Efendi, Mur'i t'tevârîh, 1, haz. M. Münir Aktepe, İstanbul, İstanbul Üniversitesi Edebiyat Fakültesi Yayınları, 1976, s. 123; Yorulmaz, Koca Râgıb Paşa Dîvânı (Araştırma ve Metin), s. 6, 8-10; Aydıner, Koca Râgıb Mehmed Paşa- Hayatı ve Dönemi: 1699-1763, s. 160; Hasan Gültekin, "Koca Râgıb Paşa Münşeâtında Nâdir Şah ve Caferî Mezhebi Tartışmalarına Dair Mektuplar”, Türk Kültürü ve Hacı Bektaş Velî Araştırma Dergisi, 76, 2015, s. 55-78.

31 Joseph Von Hammer, Büyük Osmanlı Tarihi, 8, haz. Erol Kılıç-Mümin Çevik, İstanbul, Üçdal Neşriyat, ts., s. 51; Şem 'dânîzâde, Mur 'i 't-tevârîh, s. 108, 109; Aydıner, "Dönemin Kaynakları ve Arşiv Belgelerine Göre Koca Râgıb Mehmed Paşa’ya Dair Bir Portre”, s. 8, 9.

32 Mahzar: Müteaddit imzayı hâvi olarak bir madde hakkında yazılıp resmi makamlardan birine verilen kâğıt, arzuhal hakkında kullanılır bir tabirdir. Bk. Pakalın, Osmanlı Tarih Deyimleri ve Terimleri Sözlüğ̈̈, 2, s. 391.

33 Yorulmaz, Koca Râgıb Paşa Dîvânı (Araştırma ve Metin), s. 11-12; Aydıner, "Dönemin Kaynakları ve Arşiv Belgelerine Göre Koca Râgıb Mehmed Paşa'ya Dair Bir Portre”, s. 10.

34 Aydıner, "Dönemin Kaynakları ve Arşiv Belgelerine Göre Koca Râgıb Mehmed Paşa'ya Dair Bir Portre", s. 11. 
Kelâl ${ }^{35}$ geldi tasarrufdan Ümm-i Dünyâ'y1, Yeter şu Kâhire'nün kahrı, azm-i Rûm idelüm ${ }^{36}$

Sonunda Râgıb Paşa'nın mektubuna bir cevap gelmiş ve 1161/12 Eylül 1748 'de Kubbe vezirliğ ${ }^{37}$ ve Nişancıl1k ${ }^{38}$ pâyeleriyle İstanbul'a çağrılmıştır. Fakat daha İstanbul'a ulaşmadan bu görevi, Aydın muhassıllığına tebdil edilmiştir (Aralık 1748). Burada da başarılı pek çok icraata imza atmasına ve daha iki-üç sene geçmesine rağmen Rakka eyaletine vali olarak gönderilmiştir (Safer 1164Ocak 1751). Kuzeydoğu Suriye sınırlarında kalan Rakka bölgesi, bugün olduğu gibi o gün için de oldukça netameli bir bölgeydi. Kürt ve Türkmen aşiretlerinin bir türlü bitmek bilmeyen kavgaları, oraya gelen valileri usandırmıştı. Râgıb Paşa, bulunduğu yerde etnik kavgaları ortadan kaldırmak ve bölgenin kalkınmasını sağlamak gibi bir takım ıslâhî çalışmalarla işe koyulmuştur. Nitekim bir kez daha yaptığı başarılı icraatlar ile İstanbul'da adından söz ettirmiş ve Rakka halkının da gönlünü kazanmıştır. Âdeten eyaletlerde yılda bir kere vali değiştirilmesine rağmen Râgıb Paşa dört seneden daha fazla burada kalmıştır. Bu esnada, “Kâhire'de uyguladığı önce yumuşak sonra sert siyasetini burada da uygulamış ve şerlerinden illallah edilen Millî-Kebir aşiretinin isyancıbaşısı Beşşar'ın başını, yolunu takip edeceklere ibret olması için kavun misali yerde yuvarlatmıştır."’39

Râgıb Paşa, bu kez farklı bir usul ile yani Abdullah Paşa ile becâyiş yapılarak görev için 24 Ağustos 1755 tarihinde Halep eyaletine gönderilmiştir. Burada eyaletin kalkınmasına yönelik önemli adımlar atmıştır. Öyle ki Halep’te dokunan kumaşlardan alınan vergilerle ilgili zuhur eden probleme karşı Râgıb Paşa'nın ortaya koyduğu re'y ve muhassılının marifetiyle yapılan düzenleme, büyük takdir toplamış, hatta Kadı Yahya Efendi tarafından şer'iyye siciline kaydedilip, ihtimal dâhilindeki müracaatlar için dustûru'l-amel ${ }^{40}$ kılınmıştır. Râgıb Paşa, başarılı icraatları neticesinde yerli halkın ve yabancı koloni mensuplarının takdirini ve sevgisini kazanmış, "kendisiyle görüşülüp konuşulabilinmesi imtiyaz olarak addedilen bir şahıs" olmuştur. Ayrıca İngilizler, Râgıb Paşa'yı oldukça liberal düşünceye sahip biri olarak görmüşlerdir. ${ }^{41}$

\section{Bitkinlik, yorgunluk.}

36 Demirbağ, "Koca Râgıb Paşa ve Dîvân-ı Râgıb”, s. 305.

37 Bk. Pakalın, Osmanlı Tarih Deyimleri ve Terimleri Sözlüğ̈̈, 2, s. 307-308.

38 Bk. Pakalın, Osmanl Tarih Deyimleri ve Terimleri Sözlüğ̈̈, 2, s. 697-700.

39 Aydıner, "Dönemin Kaynakları ve Arşiv Belgelerine Göre Koca Râgıb Mehmed Paşa'ya Dair Bir Portre", s. 12.

40 “Ahkâmiyle amel olunmak lâzırm gelen kanun ve kaide yerinde kullanılır bir tabirdir." Pakalın, Osmanlı Tarih Deyimleri ve Terimleri Sözlügü, 1, s. 484.

41 Aydıner, "Dönemin Kaynakları ve Arşiv Belgelerine Göre Koca Râgıb Mehmed Paşa'ya Dair Bir Portre", s. 13. 
Aradan iki yıl gibi (18 ay) bir zaman geçmemişti ki bu kez Râgıb Paşa, sadrazamlık $^{42}$ (başbakanlık) için İstanbul'a çağrılmış, o da hiç vakit kaybetmeden Halep'ten yola revan olmuş (22 Ocak 1757) ve elli günlük bir yolculuğun ardından İstanbul'a gelerek mühr-i hümâyûnu bizzat Padişah'tan 1171/20 Mart 1757'de almıştır. Böylelikle de devlet hizmetlerinde en aşağı makamdan başlayarak, kademe kademe deruhte ettiği her bir vazifede bürokrasi ve diplomasi alanında engin tecrübeler edinerek Osmanlı Devleti'nin yurttaşı olan bir kişinin yükselebileceği en son makama/sadrazamlığa kadar terakkî etmiştir. Koca Ragıb Paşa, Padişah III. Osman'ın sonuncu, III. Mustafa'nın ilk sadrazamı olarak 1757-1763 yılları arasında 6 yıldan fazla bir süre Osmanlı Devleti'nde 161. sadrazam olarak görev yapmıştır. ${ }^{43}$

İmparatorluk için, "kaderin yolladığ bir armăgan" Paşa'nın sadrazamlık makamına gelişi, halk ve dostları tarafından büyük sevinçle karşılanmış ve o gün için pek çok tarih düşürülmüştür. ${ }^{45}$ Râgıb Paşa, uzun yılların vermiş olduğu tecrübe ve müdebbir vasfiyla kısa zamanda payitahtta da âsâyişi sağlamak, Akdeniz ticaretini sekteye uğratan etkenleri ortadan kaldırmak ve halkın uzun zamandan beri içinde bulunduğu iâşe sıkıntısını izale etmek gibi konularda çözüme yönelik epeyce icraatlar gerçekleştirmiştir. Hatta bu esnada halka zulmeden bazı paşaları tard veya katl etmekten de imtina etmemiştir. ${ }^{46}$

Râgıb Paşa, III. Osman'ın ölmesi ve ardından 16 Safer 1171-30 Ekim 1757'de sabaha karşı III. Mustafa'nın cülus merasiminin yapılması ile yeni padişahın da ilk sadrazamı olarak görevine devam etme imkânı bulmuştur. ${ }^{47}$ Osmanlı Devleti'nde yıllardan beri ilk defa Râgıb Paşa'nın sadâret döneminde (1761 yılında), bütçe gelirleri giderlerin önüne geçmiş, bundan dolayı da III. Mustafa'nın med-

42 Bk. Pakalın, Osmanlı Tarih Deyimleri ve Terimleri Sözlüğü, 3, s. 81-88.

43 Baykal, "Râgıb Paşa", 9, s. 595; Muhammed Ferid Bey el-Muhâmî, Târihu'd-devleti'lOsmâniyye, thk. İhsan Hakk1, Beyrut, Dâru'n-nefâis, 1981, s. 327; Ziriklî, el-A 'lâm, 6, s. 123; Demirbağ, "Koca Râgıb Paşa ve Dîvân-1 Râgıb", s. 10. Sadrazamlık yıllarına dair detaylı bilgi için bk. Aydıner, "Koca Râgıb Mehmed Paşa - Hayatı ve Dönemi: 1699-1763”, s. 214- 237.

44 Lamartine, Sona Doğru (Türkiye Tarihi), 6, s. 1580.

45 Önem verilen ya da dikkat çeken bir olayın yılını veya tarihini göstermek üzere ebced hesabıyla bir cümle, bir mısra ya da bir beyit söyleme/yazma sanatıdır. Bk. Turgut Karabey, "Tarih Düşürme", Türkiye Diyanet Vakfi İslam Ansiklopedisi, 40, İstanbul, Türkiye Diyanet Vakfı Yayınlar1, 2011, s. 80-82.

46 Aydıner, "Dönemin Kaynakları ve Arşiv Belgelerine Göre Koca Râgıb Mehmed Paşa'ya Dair Bir Portre", s. 15.

47 el-Muhâmî, Târihu'd-devleti'l-Osmâniyye, s. 329; Aydıner, "Dönemin Kaynakları ve Arşiv Belgelerine Göre Koca Râgıb Mehmed Paşa’ya Dair Bir Portre”, s. 16. 
hini kazanmış ve nitekim Padişah, onu dul kız kardeşi Saliha Sultan ile evlendirerek aralarındaki ilişkiyi daha da pekiştirmiştir. Râgıb Paşa'nın Nebile Hanım ve Saliha Sultan adında iki zevcesi ve Nâile Hanım ile Lebibe Hanım adında da iki kızı olmuştur. ${ }^{48}$

Râgıb Paşa'nın o dönemde çok az kişiye nasip olan sadrazamlık görevi ömrünün sonuna kadar olmak üzere altı yıl sürmüştür. Paşa, 25 Ramazan 1176/8 Nisan 1763 tarihinde Perşembeyi Cumaya bağlayan gecede dâimu'l-harâre ve'd-dolab denilen hastalık sebebiyle vefat etmiștir. ${ }^{49}$ Cenaze namazı Fatih Camii'nde cuma namazını müteakip kılınmış, ardından da tabutu kendisinin Laleli/Koska'da inşa ettirdiği ve vefatından bir ay önce açılışı gerçekleşmiş olan kütüphanesine taşınarak hazîreye defnedilmiştir. Âdeta öldükten sonra bile kitap kokusu ve sıbyan mektebinden gelen sadâdan ayrı kalmak istemeyen bu bilge adamın kaybına, halk çok üzülmüş, şairler birçok tarih düşürmüştür. ${ }^{50}$

\section{2. İlmî Hayatı}

Râgıb Paşa, yukarıda geçtiği üzere Osmanlı devlet adamları içerisinde başarı11 bir bürokrat ve diplomat olması yanında, bu yönü kadar olmasa da ilmî yönden de bazı çabalar ve hizmetler içinde olmuştur. Nitekim kendine ait bir kütüphane inşa ettirmiş ve içinde -görev îcabı gittiği Rakka, Haleb, Dımaşk, Hicaz, Mısır, Azerbaycan, Aydın ve diğer bölgelerden topladığ çok sayıda kitabı dercetmiştir. Yine Doğuya ait derin birikimiyle yetinmeyip Avrupa'dan da kitaplar getirtmiş, Newton ve Volter gibi aydınların eserlerini tercüme ettirerek Batı dünyasından da istifade etmeye çalışmış, Batılılara ait bazı mühim eseri de kitaplığına katmıştır. Böylece zengin bir kütüphane oluşturmuştur. ${ }^{51}$

Şairliği, hukuk bilgisi ve gittiği her yerde âlim ve şairlerle dostluk kurmas1 da onun ilminin ve tecrübesinin artmasına ziyadesiyle katkıda bulunmuştur. Esasen kendisi de konağını bir ilim ve irfan merkezi haline getirmiş, daima

48 Aydıner, "Dönemin Kaynakları ve Arşiv Belgelerine Göre Koca Râgıb Mehmed Paşa’ya Dair Bir Portre", s. 17.

49 Mesut Aydıner ve daha birçok araştırmacının tezlerinde Râgıb Paşa'nın bu hastalığ prostat olarak ifade edilmektedir. Bk. Aydıner, "Koca Râgıb Mehmed Paşa- Hayatı ve Dönemi: 16991763”, s. 237, 238. Fakat bu bilgiye rağmen Mahmud ed-Duğeym çalışmasında, Râgıb Paşa'nın tifo hastalığı sebebiyle vefat ettiğini kaydetmektedir. Bk. ed-Duğeym, Fihrisu'l-mahtûtât, 1, s. 149.

50 Yorulmaz, Koca Râgıb Paşa Dîvânı (Araştırma ve Metin), s. 20-21; Aydıner, "Dönemin Kaynakları ve Arşiv Belgelerine Göre Koca Râgıb Mehmed Paşa'ya Dair Bir Portre”, s. 23.

51 Bk. Mollaibrahimoğlu, Koca Râgıb Mehmed Paşa ve Hâşiye 'Alâ Tefsiri'l-Kâdî el-Beydâvî Adlı Eserin Tahlîli, s. 32. 
burada ilmî sohbetler ve münakaşalar olmuştur. Sohbet meclislerine büyük âlimlerinden İbrahim el-Halebî, Ezher Şeyhi İbrahim b. Mustafa el-Hanefî, Şâfiî müftü Abdülmevâhib, Muhammed b. Ömer el-Arabî, Abdülaziz b. Muhammed er-Rahbî, Mısır Müftüsü Cebertî, Ermeni Patriği Hagop Nalyan gibi her kesim ve milletten insanların yanı sıra şeyhülislamlardan Mehmed Esad, Çelebizâde Asım, Veliyyüddin Efendi gibi zatlar, Fıtnat Hanım, Haşmet, Nevres, Ahmed Nüzhet gibi şairler, İpsilanti gibi doktorlar ve daha başka pek çok dostu katılmıştır Bu sohbet ve tartışmalarda memleketlerin âlimleri, kadıları ve müftîleri kendisiyle tartışmaya kadir olmadıkları gibi, onun yanında sohbet etmekten bile imtina etmişlerdir. Yakınları onu hep, "vakitlerinin çoğunu kitap okuyarak geçiren ve başlıca zevki, ilmî meseleler ile uğraşmak olan" biri olarak tavsif etmişlerdir. ${ }^{52}$ Vefat ettiği odasındaki eşyalar arasında kendi yazdığı kitaplarının dışında onlarca kitabın bulunmuş olması hakkında söylenilen bu sözleri teyit etmektedir. Bütün bunlar onun ilim yönündeki gayretlerini göstermektedir. ${ }^{53}$

Yine reisülküttab döneminde, meşhur âlimlerden olan Mısırlı İbrahim el-Halebî'yi kendine hoca tayin ettirmesi, Bağdat'ta, Misır'da, Halep'te, İstanbul'da velhasıl bulunduğu her yerde etrafinda daima ilim ehlinden halkalar oluşturması; inşa ettirdiği kütüphanesindeki kitapların birçoğunun içinde kendisine ait notların bulunması da onun ilme olan merakını, ilgisini yansıtmaktadır. Bu meyanda Prusya Elçisi Rexsin'in onu, "Bir Paşa'dan çok ömrünü kitaba ve ilme vermiş bir derviş" şeklinde tanımlaması da oldukça manidardır. Yanı sıra Avrupa ilmini, havadisini ve siyasetini yakından takip etmesiyle de dikkat çekmektedir. Nitekim o, bu yönleri ile Tanzimat' 1 hazırlayan aydınlardan birisi veya batı ilmine ve tarihine ilgi duyan 19. yy. aydınlarının öncülerinden sayılabilmektedir. ${ }^{54}$ Bütün bunlar onun ne kadar entelektüel bir kişiliğe sahip olduğunun en somut göstergeleridir. ${ }^{55}$

Râgıb Paşa Mısır'da Ezher Üniversitesinde Ruvvaku'ş-Sâm Şeyhi Ebu'r-Rıza Abdullatîf $b$. Ahmed b. Muhammed b. Ali ed-Dımeşkî el-Ezherî el-Mektebî'den

52 Aydıner, "Dönemin Kaynakları ve Arşiv Belgelerine Göre Koca Râgıb Mehmed Paşa'ya Dair Bir Portre", s. 23.

53 Mollaibrahimoğlu, Koca Râgıb Mehmed Paşa ve Hâş̧iye 'Alâ Tefsiri'l-Kâdî el-Beydâvî Adlı Eserin Tahlîli, s. 33.

54 Bk. Aydıner, "Dönemin Kaynakları ve Arşiv Belgelerine Göre Koca Râgıb Mehmed Paşa’ya Dair Bir Portre", s. 23-24.

55 Mollaibrahimoğlu, Koca Râgıb Mehmed Paşa ve Hâş̧iye 'Alâ Tefsiri'l-Kâdî el-Beydâvî Adlı Eserin Tahlîli, s. 24. 
$(1162 / 1749)^{56}$ icâzet (meslekte yeterlilik izni, diploma) ${ }^{57}$ almıştır. ${ }^{58} \mathrm{Bu}$ icâzet şu

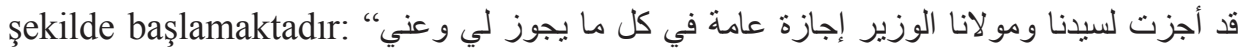
"رو ايته بالثرط المعتبر عند أهل الأثر... (Seyyidimiz ve mevlamız olan vezire/Râgıb'a, benim için ve yine benden rivâyeti caiz olan bütün bilgileri, eser/nakil ehlinin muteber gördüğü şartlar doğrultusunda rivâyet etmesi konusunda kendisine umumi bir icâzet/izin verdim...) Bu icâzetin kapsadığ ilimler ise şunlardır: Sahihu'l-Buhârî ve onun el-Askalânî ve el-Kastallânî'ye ait olan iki şerhi, Sahih-i Müslim, Sünen-i Ebî Dâvud, Sünen-i Tirmizî, Sünen-i Nesâ̂, Sünen-i İbn Mâce, el-Muvatta, Kâdî İyâd'a ait olan eş-Şifâ fì ta 'rîf hukîki'l-Mustafa, el-Beğavî'nin Mesâbîhu's-sünne'si, el Hatib'in Mişkâtu'l-mesâbîh'i, el-Kâdî Ebu'l-Fazl İyâz'a ait olan Meşâriku'l-envâr, el-Câmiu's-sağîr ve İmam Nevevî'ye ait olan el-Ezkâr, Tefsiru'l-Beydâvî, Tefsiru Ebi's-Suûd, el-Futûhâtu'l-Mekkiyye, Kâmûsu'l-Fîrûzâbâ$d \hat{\imath}$, İbn Esir'in en-Nihaye ve diğer musannef ve merviyyât1, Şeyh Şerafuddin elBûsîrî'nin merviyyâtı ve manzûmâtı, el-Cezûlî'nin Delâilu'l-hayrât'1 ve Ahmed en-Nehlî el-Mekki'den alınan Tarîkatu'n-Nakşibendiyye ve bunun dışında evrâd, ezkâr ve ed'iyeler... Bu icâzeti yazan, el-Fakir Ebu'r-Rıza Abdullatîf b. Ahmed ed-Dımeşkî'dir. ${ }^{59}$ Allah onun günahlarını affetsin, ayıplarını örtsün (Âmin). Bu icaze $^{60}$ Ramazan ayının ilk onuna tevafuk eden $110 \wedge / 1745$ senesinde yazılmıştır. ${ }^{61}$

56 el-Mektebî eş-Şâfii ed-Dımeşkî olarak bilinen Abdullatif b. Ahmed b. Ali, Mısır'da ikamet eden ve birçok ilimde behresi olan fâzıl bir âlimdi. Özellikle hesap, felek, hey'et ve takvim bilgisinde meşhur idi. Dımaşk şehrinde doğmuş ve ilk ilmî tahsilini burada almıştır. Daha sonra Mısır'a geçmiş ve ölünceye kadar orada iskân etmiştir. Oranın en meşhur âlimlerinden ilim tahsil ettikten sonra öğrenciler yetiştirerek namı bütün beldeye yayılmıştır. Hayatının son zamanlarında bunları terk ederek her sene hacca gitmeye özen göstermiştir. Nitekim Arafat dağında 1749 senesinde vefat ederek orada gömülmüştür. Bk. Huseynî, Silku'd-durer fí a 'yâni'l-karni's-sânî 'aşer, 3, s. 118-119; ed-Duğeym, Fihrisu'l-mahtûtât, 1, s. 153.

57 Bk. Cemil Akpınar, "İcâzet”, Türkiye Diyanet Vakfi İslam Ansiklopedisi, 21, İstanbul, Türkiye Diyanet Vakfi Yayınları, 2000, s. 393-400.

58 Bu icâzet Râgıb Paşa Kütüphanesi'nde 1471/2 demirbaş numarada muhafaza edilmektedir.

59 Râgıb Paşa, Abdullatif' in kendi şeyhlerinden/hocalarından olduğuna hâşiyesinde de işaret etmektedir. Bk. Ragıp Paşa, Hâş̧iyetu Râgıb Paşa ala Tefsiri'l-Beydâvî, Süleymaniye Kütüphanesi, Râgıb Paşa, nr. 70, vr. 523b.

60 Et-Tehânevî, Istılâhâtu'l-funûn adlı eserinde icazetin beş kısmından bahsetmektedir... Beşincisinin de bir hocanın karşısındaki kişiye, "sana sahip olduğum bütün icazetlerimden icazet verdim” anlamında kullanılan 'İcâzetu'l-mecâz' olduğunu belirtmektedir. Yani “benim icazet aldığım bütün bilgileri sen de nakledebilirsin" anlamında kullanılmaktadır ve bu, sahih bir icazet türü olarak addedilmektedir. Bk. Muhammed A lâ b. Ali b. Muhammed Hâmid et-Tehânevî el-Faruki, Keşşâfu istılâhâti'l-funûn ve'l-ulûm, 1, thk. Ali Dehrûc, Beyrut, Mektebe Lübnan, 1996, s. 99-100. Muhtemeldir ki Paşa'ya verilen bu umumi icazet de bu şekildedir.

61 Ed-Duğeym, Fihrisu'l-mahtûtât, 1, s. 153. 
Yine Râgıb Paşa, Muhaddis Edîbu'l-Ârif Ali b. Mustafa el-Mîkâtî el-Halebi'den ${ }^{62}$ de icâzet almıştır. ${ }^{63}$

Bütün bunlar büyük bir siyasi deha olması yanında Rağıb'ın aslında iyi bir İslam âlimi olduğunu da göstermektedir. Aşağıda bahsedeceğimiz hâşiyesini de bu ilmî yetkinlik ve tecrübeyle yazmıştır.

\section{Râgıb Paşa'nın Beydâvî Tefsiri Üzerine Yazmış Olduğu Hâşiyesi}

Rağıp Paşa, yukarıda da belirtildiği üzere esas itibariyle bir devlet adamı ve bürokrat olarak öne çıkmıştır ve bu bağlamda çok önemli hizmetler ifa etmiştir. Ancak o bunlarla yetinmemiş, küçüklüğünde ve gençliğinde aldığı iyi eğitim sayesinde ilimle iştigal etmekten de geri durmamıştır. Hâş̧iye alâ tefsîri'l-Kâdî el-Beydâvî adlı eseri bu gayret ve iştigalinin bir neticesi olarak ortaya çıkmıştır.

\subsection{Hâşiye'nin Müellife Nispeti ve Yazma Nüshasının Tavsifi}

Araştırmamıza konu olan bu hâşiyenin tek ve tam nüshası, Süleymaniye Kütüphanesi Râgıb Paşa nr. 70'de bulunmaktadır. Nüsha okunaklı, güzel talik hattıyla bizzat müellifi yani Sadrazam Râgıb Paşa tarafından yazılmıştır. Nüsha 304x177, 205x91 mm ebadinda olup 564 varak $^{64}$ ve tam bir sayfa ortalama 29 satırdan oluşmaktadır. Râgıb Paşa, bu hâşiyeyi ne zaman ve nerede yazdığına dair ferağ kaydında şu bilgileri kaydetmiştir:

"Envâru't-tenzîl ve esrâru't-te'vîl' i, mutâlaa etmeye Kahire'deki valiliğim sırasında başladım, Rakka'da mâlikane vasfiyla görevli olarak bulunurken de tamamladım. Bu esnada gücüm nispetinde tedavülde bulunan birkaç hâşiye ve yaygın olan şerhlerinden yararlandım. Ayrıca et-Tefsîru'l-kebîr, İş̧âdu'l-akli s'selim, Tefsir-i Nîsâbûrî ve özellikle de mevcut olan şerh ve hâş̧iyeleriyle birlikte el-Keş̧̧̂ff'a da müracaatlarda bulundum. Ayrıca o günler/yıllarda bir yandan hükümet işleriyle meşgul oluyor, bir yandan da bir beldeden diğer beldeye taşınmanın meşakkatiyle ibtilâ olunuyordum... Allah Teâlâ'dan, bu lezzeti (tefsir ilmiyle iştigal lezzetini) defalarca tadabilmem için vakit vermesini ve umudumu/

62 Ali b. Mustafa ed-Debbâğ Ebû'l-Feth el-Mîkâtî eş-Şâfii el-Halebî (1174/1760)dir. Buhârî Şerhi, Delâilu'l-hayrat hâşiyesi ve takrizleri mevcuttur. Ayrıca Râgıb Paşa Kütüphanesi’nde mahtûtâtı mevcuttur. Bk. Ed-Duğeym, Fihrisu'l-mahtûtât, 1, s. 154.

63 Bu icâzet Râgıb Paşa Kütüphanesi'nde demirbaş nr. 1471/4 'de bulunmaktadır. Bu icazetin 1756 senesinde verildiği kaydedilmiştir. Bk. Ed-Duğeym, Fihrisu'l-mahtûtât, 1, s. 154.

64 ed-Duğeym varak sayısını 598, sayfa satır sayını da 28 olarak vermiştir. Muhtemeldir ki bu durum, dijital ortamdaki sayfa sayısı nazar-1 dikkate alınarak yapılmıştır; çünkü nüshanın varak sayısı 564'te bitmektedir. Ayrıca bu sayı ( $564:$ g) şeklinde nüshanın ilk varakında da belirtilmiştir. Bk. Mahmud es-Seyyid ed-Duğeym, Fihrisu'l-mahtûtât, 3, s. 195-200. 
şevkimi arttırmasını talep ediyorum. Ben, mevhibeler/ikramlar sahibi Rabbinin nimetlerine muhtaç olan vezirler/bakanlar arasında Râgıb olarak çağrılan Mehmed'im. İşte bu (nüsha), Şaban ayının son günlerinde izzet ve şeref sahibi olanın (Hz. Peygamber'in) hicret senelerinden 1168 (m. 1755)'de tamamlanmıştır." ${ }^{65}$

Râgıb Paşa -ketebe kaydından da anlaşılacağı üzere-, bu hâşiyeyi, yaklaşık on bir yıl (1744-1755) gibi uzun bir zaman zarfinda ve birçok gâileler/meşakkatler eşliğinde tamamlayabilmiştir. Böylece bir Osmanlı âlimi tarafından yapılmış tam bir Beydâvî hâşiyesi daha meydana gelmiştir.

Hâşiyenin müellif hattıyla mevcut nüshasını şekilsel açıdan değerlendirdiğimizde ciltsiz olduğu, ilk varakında " 29 و 29 " şeklinde varak sayfası ve satır sayısı bilgisinin, daha sonraki iki varakta ise hâşiyenin değil Beydâvî tefsirinin fihristinin bulunduğunu görmekteyiz. Fihristten sonraki varakta ise, Râgıb Paşa'ya ait bir mühür bulunmaktadır. Yine bu mühür ara ara bazı sayfalarda ve hâşiyenin son kısmında da kullanılmıştır. Bu mührün üzerinde şu cümleler yazı1-

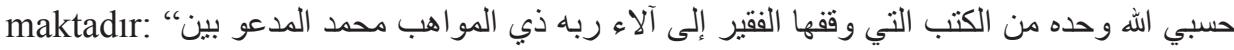
"الصدور بالر اغب وكفى عبده." (Her işimde bir olan Allah bana kâfidir, o bana yeter. (Bu nüsha) İkramlar sahibi rabbinin nimetlerine muhtaç olan, ileri gelenler arasında Râgıb olarak anılan kişinin vakfettiği kitaplardandır. O, kuluna kâfidir).

$\mathrm{Bu}$ nüshada Beydâvî tefsiri, nesih hattıyla kısmen harekeli bir biçimde ana metin olarak yazılmıştır. Beydâvî tefsirinin hattı, Ali b. Muhammed adında bir zata aittir. Râgıb Paşa'nın notları ise bu yazma Beydâvî nüshasının kenar kısımda hâşiye olarak bulunmaktadır. Fakat bazen hâşiye notları için kenar kısımlar yeterli gelmeyip tefsir metninin dışında hâşiye için özel varaklar kullanılmıştır. ${ }^{66}$ Muhtemelen Paşa, hâşiye notları için daha önce yazılmış olan bu nüshayı kullanmakla ileride onu okuyacak olanlara her iki metni yani kaynak metin ile hâşiye metnini aynı anda mütâlaa edebilme firsatını sunmayı arzulamıştır. Ayrıca yer yer nüshadaki bazı varakların sonunda o sayfaların nerede yazıldığına dair bilgiler de verilmiştir. ${ }^{67}$ Nüshanın bazı varaklarında hafif zedelenmeler ve sayfa sayılarında da küçük karışıklıklar müşahede edilmektedir. ${ }^{68}$ Fakat sayfa siteminde böyle bir

65 Ragıp Paşa, Hâş̧iyetu Râgıb Paşa ala Tefsiri'l-Beydâvî, Süleymaniye Kütüphanesi, Râgıb Paşa, nr. 70, 564a.

$66 \mathrm{Bu}$ durum, daha çok nüshanın ilk yirmi varağında gerçekleşmektedir. Yine 400b, 401a, 502b ve 503a gibi bazı varakların bulunduğu kısımlarda da hâşiye metni için ekstra sayfalar kullanılmıştır. Bu sayfaların ekserisinde birtakım izahlar bulunmakla birlikte üzerinde hiçbir notun olmadığı sayfalar da müşahede edilmiştir. Ayrıca Râgıb Paşa, hâşiye notları için özel olarak koyduğu bu sayfaları bağımsız olarak numaralandırma da yapmıştır.

67 Bu tarz örnekler için bk. Ragıp Paşa, Hâş̧iyetu Râgıb Paşa, 7a, 120b, 121a, 496b, 497b.

68 Şöyle ki, vr. 205’ten 235'e kadar olan kısım numaralandırılmamıştır. Bu kısımdan sonra 235 
karışıklık olmasına rağmen metinde -kontrolümüz neticesinde- herhangi bir eksiklik görülmemiştir. ${ }^{69}$

Hâşiyeler kendi aralarında üslûb yönüyle farklılık arz etmektedir. Râgıb Paşa'nın üslûbuna baktığımızda onun, üzerine hâşiye yazmak için seçtiği tefsir ibaresine, kırmızı mürekkeple yazılan "قوله" kelimesiyle işaret ettiğini; hâşiye düşülecek cümlenin sadece baş kısmını zikrederek geri kalan kısm1 "إلى "خصده" cümlesinden yapılan “الخ" ve yine musannif Beydâvî”yi, "قاله الصص أو استعمله المص" (Onu musannif söyledi veya musannif kullandı) şeklindeki kısaltmalar ile imlemekte olduğunu müşahede etmekteyiz. ${ }^{70}$

Râgıb Paşa Beydâvî’nin muradını ortaya koymak için “ey, ya'nî, fî, yurîdu ve yuhtemel" gibi formları ve nadir de olsa soru-cevap üslûbunu kullanmaktadır. ${ }^{71}$

Yine Râgıb Paşa hâşiyesinde zaman zaman bugün edisyon kritik veya metin tahkiki olarak adlandırılan bir yöntemle nüshalar arasındaki yazım farklarına da değinmektedir. ${ }^{72}$

Kapsamı bakımından incelediğimizde Ragıb Paşa Hâşiyesi, tam hâşiyelerden addedilebilir. Zira Hâşiye, Beydâvî tefsirinin başıyla başlamakta ve sonuyla bitmektedir. Başka bir ifadeyle Beydâvî tefsirinin, dolayısıyla da Kur'an'ın tamamını kapsamaktadır. Hâşiyedeki izahların, Fâtiha ve Bakara suresinin ilk iki sayfasını kapsayan kısımlarda yoğunluk arz ettiği, Hicr suresine kadar talikat şeklinde seyrettiği, Nahl suresinden sonra kısmen, son cüzlerde ise tekrar bir yoğunluk gösterdiği görülmektedir.

\subsection{Hâşiyenin Kaynakları}

Râgıb Paşa ferağ kaydında hâş̧iyesini ne zaman ve nerede kaleme aldığını belirttikten sonra hangi kaynaklardan yararlandığını da şu cümlesiyle ifade etmektedir: 'Bu esnada yanımda bulunan et-Tefsîru'l-kebîr, İş̧âdu'l-akli's-selim, Tefsir-i Nîsâbûrî ve özellikle de mevcut olan şerh ve hâşiyeleriyle birlikte el-Keşşaf'a murâcaatlarda bulundum."

şeklinde iki sayfa eksik olarak numaralandırılmaya devam edilmiştir. Yine 247'inci sayfa 249 olarak gösterilmiştir.

69 Mollaibrahimoğlu, Koca Râgıb Mehmed Paşa ve Hâş̧iye 'Alâ Tefsiri'l-Kâdî el-Beydâvî Adlı Eserin Tahlîli, s. 43.

70 Ragıp Paşa, Hâş̧iyetu Râgıb Paşa, vr. Mukaddime, Hâşiye, 2b, 4a, 5d, 5b, vr. 6b, 11a.

71 Bk. Mollaibrahimoğlu, Koca Râgıb Mehmed Paşa ve Hâşiye 'Alâ Tefsiri'l-Kâdî el-Beydâvî Adlı Eserin Tahlîli, s. 44.

72 Bu tarz örnekler için bk. Ragıp Paşa, Hâşiyetu Râgıb Paşa, vr. Mukaddime, hâşiye 2b, 3a, 3b, 517 a. 
Bunlarla birlikte Râgıb Paşa'nın hâşiyesinde iktibasta bulunduğunu ve kendisinin de isimlerini sarih bir şekilde beyan ettiğini müşahede ettiğimiz bütün kaynakları kronolojik olarak şöylece sıralayabiliriz: İbn Habib en-Nîsâbûrî'nin Tefsiru'l-Kur'âni'l-Kerîm (Tefsiru'n-Nîsâbûrî) adlı eseri; Ebü'l-Hasan el-Vâhidî en-Nîsâbûrî'nin (v. 468/1076) el-Vasît fî tefsîri'l-Kur'âni'l-mecîd ve et-Tefsiru'l-basît adlı eserleri; Zemahşeri'nin (v. 538/1144) el-Keşşaf an hakâiki gavâmidi't-tenzîl adlı eseri; Fahruddin er-Râzî'nin (v. 606/1210) Mefâtîhu'l-ğayb/ et-Tefsîru'l-kebîr adlı tefsiri; İbnu't-Temcîd Muslihuddin Mustafa b. İbrâhim el-Hanefî̀ er-Rûmî'nin (v. 855/1451) Hâşiye alâ Envâri't-tenzîl'i; İmâdüddin Mansûr b. el-Hasan b. Ali b. Sadriddin el-Kureşî el-Kâzerûnî’nin (v. 860/1456) Hâsşiye alâ Envâri 't-tenzîl'i; Molla Hüsrev'in (v. 885/1480) Hâssiyetu evâili tefsiri'l-Beydâvî'si, Sinan Efendi/Hoca Sinan'ın (v. 891/1486) Hâş̧iye alâ tefsîri'l-Beydâvî'si; Zekeriyya el-Ensâri'nin (v. 926/1520) Fethu'l-celîl bi-beyâni hafiyyi Envâri 't-tenzîl'i; İsâmuddin el-İsferâyînî‘nin (v. 945/1538) Hâsşiye ala tefsiri'l-Beydâvî'si; Sâdî Çelebi'nin (v. 945/1539) el-Fevâidu'l-behiyye'si; Muhyiddin Şeyhzade'nin (v. 950/1543) Hâşiye ala tefsiri 'l-Beydâvî̀'si; Ebussuûd Efendi el-İmâdî'nin (v. 982/1574) İrşâdu'l-akli s-selim ilâ mezâye'l-Kitabi'l-Kerim'i; Abdulhakim es-Siyalkûtî'nin (v. 1067/1657) Hâşiye ala tefsiri'l-Beydâvî̀si; Şihabuddin Hafâcî'nin (v. 1069/1659) İnâyetu'l-Kâdî ve kifâyetu'r-Râzi ala tefsiri'l-Beydâvî'si ve şurûhu'l-Keşşâf diye nitelediği eserler. Bunların arasında en çok başvurduğu kaynak Hafâcî'nin İnâyetu'l-Kâdî adlı hâşiyesidir. ${ }^{73}$

Râgıb Paşa dolaylı yoldan bu eserlerin kullanmış olduğu diğer kaynakları da kullanmış bulunmaktadır, fakat biz burada sadece direkt alıntı yaptığı birincil kaynaklar niteliğindeki eserlerin isimlerini vermekle iktifa etmeyi uygun gördük.

Râgıb Paşa, kaynaklardan alıntı yaparken genelde şu formel kalıpları kullan-

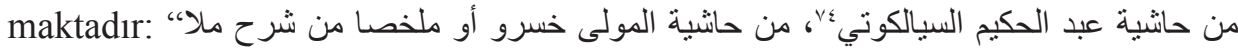

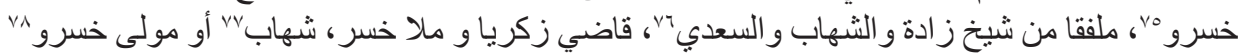

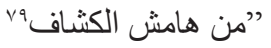

73 Mollaibrahimoğlu, Koca Râgıb Mehmed Paşa ve Hâşiye 'Alâ Tefsiri'l-Kâdî el-Beydâvî Adlı Eserin Tahlîli, s. 45-48.

74 Bk. Ragıp Paşa, Hâş̧iyetu Râgıb Paşa, hâşiye 1a, 1b, 10c, 11a,12b.

75 Ragıp Paşa, Hâş̧iyetu Râgıb Paşa, hâşiye 1a,12b, vr. 6b.

76 Bk. Ragıp Paşa, Hâşiyetu Râgıb Paşa, vr. 514b.

77 Ragıp Paşa, Hâş̧iyetu Râgıb Paşa, vr.2a.

78 Ragıp Paşa, Hâşiyetu Râgıb Paşa, hâşiye 3a, 12a. Örneklerdeki مو ş أو مولى lar Ragıb Paşa'ya aittir.

79 Ragıp Paşa, Hâş̧iyetu Râgıb Paşa, vr. 77a. 
Râgıb Paşa zaman zaman Hafâcî'nin hâşiyesi gibi detaylı bir hâşiyeden telhis yaptıktan sonra: "Kim detaylı bir şekilde öğrenmek istiyorsa bu hâşiyenin aslına müracaat etsin" veya alıntı yaptığı kaynağı zikrettikten sonra tafsilatının Şihab'da bulunduğunu ifade etmektedir. ${ }^{81}$

\subsection{Hâşiyenin Metot ve Muhtevâ Açısından Değerlendirilmesi}

Râgıb Paşa hâşiyesini telif ederken eserinde nasıl bir metot uygulayacağına dair herhangi bir bilgi vermemiştir. Mamafih Beydâvi gibi dirâyet yöntemlerinin baskın olduğu bir tefsir üzerine yazılan hâşiye niteliğindeki bu eserde, hem rivâyet hem de dirâyet yöntemlerinin kullanıldığı ve birçok hâşiyede mütâlaa edildiği gibi burada da kahir ekseriyeti, irab yönündeki açıklamaların oluşturduğu müsellem bir hakikattir. Biz de muhtelif başlıklar altında bu yöntemleri, her birine somut örnekler vererek tavzih edeceğiz. Hâşiye'nin aslı olan Beydâvî tefsiri, ağırlıklı olarak bir dirâyet tefsiri olduğundan, biz de burada Râgıb Paşa'nın hâşiyesinde önce dirâyet yöntemini nasıl uyguladığından bahsedeceğiz.

\subsubsection{Dirâyet Yöntemiyle Tefsiri}

Dirâyet yöntemi, Kur'an'1 rivâyetlerin yanı sıra, aklî ve mantıkî izahlar yaparak, ulûmu'l-Kur'an'1 hesaba katarak, sarf, nahiv, beyan, bedi, fesahat, belağat gibi dilbilimlerini nazara alarak, târihi ve dönemin bilgi birikimini göz önünde bulundurarak, kelâm, fikıh ve benzeri yönleri dikkate alarak tefsir etmektir. ${ }^{82}$ Râgib Paşa, hâşiyesinde bu yöntemi de uygulamıştır.

\subsubsection{Kur'ân'ı Kur'ân'la Tefsiri}

Kur'an'ın Kur'an'la tefsiri yöntemi her ne kadar öteden beri bir "rivâyet yöntemi" olarak kabul edilmişse de son zamanlarda yapılan çalışmalar, bu yöntemin daha ziyade bir "dirâyet yöntemi" olması gerektiğini ortaya koymuştur. ${ }^{83}$ Biz de burada Kur'an'in Kur'an'la tefsirini bir dirâyet yöntemi olarak kabul ettik ve o yüzden buna dirâyet yöntemi başlı̆̆ altında yer verdik.

80 Ragıp Paşa, Hâşiyetu Râgıb Paşa, hâşiye 10b.

81 Ragıp Paşa, Hâşiyetu Râgıb Paşa, vr.13a, 544a.

82 Bk. Muhammed Hüseyin ez-Zehebî, et-Tefsîr ve'l-müfessirûn, 1, el-Kâhire, Mektebetu Vehbe, ts., s. 183-184; Mustafa Karagöz, "Tefsirde Rivâyet-Dirâyet Ayrımının Ortaya Çıkışı ve Mahiyeti", bilimnâme, 5, 2004, s. 45-60.

83 Mustafa Öztürk, “Kur'an'ın Kur'an'la Tefsiri: Bir Mahiyet Soruşturması”, Çukurova Üniversitesi Illahiyat Fakültesi Dergisi, 8/2, 2008, s. 1-19; Muhammed Aydın, "Rivâyet Tefsiri Kavramı ve Kur'an'ın Kur'an ile Tefsiri: Eleştirel Bir Yaklaşım”, Sakarya Üniversitesi Ilahiyat Fakültesi Dergisi, 20, 2009, s. 1-22. 
Beydâvî ve onun tefsirine hâşiye yazmış olan müellifimiz Rağıb Paşa, bunların her ikisi de bu yöntemi uygulamışlardır. Özellikle müfessir Beydâvî’in yapmış olduğu tefsiri daha anlaşılır kılma ve muhtemel yanlış anlaşılmaları önleme

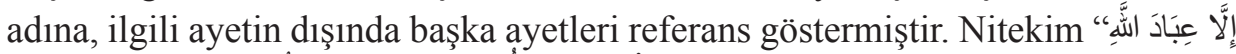

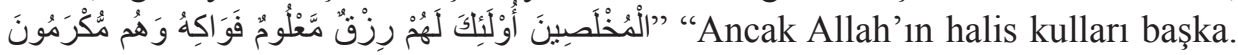
İşte onlar için belli bir rızık, meyveler vardır. Onlar ikram gören kimselerdir" "84 ayetlerinde geçen " "رزق معلوم(malum bir rızık) cümlesine binaen müfessir Beydâvî, cennet ehline verilecek rızkın "devamlı olma” özelliğini taşıdığını vurgulamıştır. ${ }^{85}$ Râgıb Paşa müfessirin bu ifadesinin mukadder bir suale cevap teşkil ettiğini söylemektedir. Şöyle ki; rızık ancak ölçülebildiği takdirde malum olabilir; fakat başka bir ayette "يرزقون فيها بغير حساب" denerek cennet ehlinin hesap edilemeyen/ölçülemeyen bir rızıkla rızıklandırılacağı belirtilmektedir. ${ }^{86}$ Bundan dolay1 müfessir buradaki bilinirliğin, "لا مقطو عة و لا ممنو عة" (tükenmeyen ve yasaklanmayan ${ }^{87}$ ayeti gibi ayetlerde ifade edildiği üzere o rızkın daimi olmak gibi bir vasfi/özelliği itibariyle olacağını izah etmektedir. ${ }^{88}$

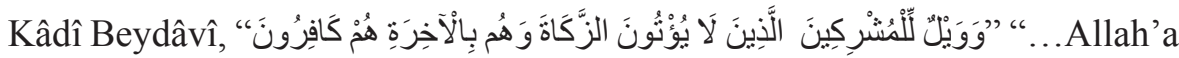
ortak koşanların vay hâline! Onlar zekâtı vermeyen kimselerdir. Onlar ahireti de inkâr ederler" ${ }^{\prime \prime 9}$ ayetlerinin tefsiri mahiyetinde şu cümleleri serdetmektedir: "Müşrikler, cimriliklerinden ve içlerinde halka karşı şefkat duyma yetisi barındırmadıklarından ötürü zekât vermezler. $\mathrm{Bu}$, büyük bir erdemsizliktir. $\mathrm{Bu}$ ayet kâfirlerin İslam'ın emirleri ile muhatap olduklarına delil teşkil etmektedir. Bir görüşe göre ise bu ayetin anlamı, 'onlar nefislerini temizleyecek olan iman ve tâatı yerine getirmezler' şeklindedir." 90

Râgıb Paşa, müfessirin bu açıklamalarına binaen hâşiyesinde şu ifadeleri kaydetmektedir: "Zekât Medine'de farz kılınmış olmasına rağmen onun bu ayette zikredilmiş olması bu surenin Mekkî olmasına engel teşkil etmez; çünkü Medine'de, elde edilen ürünlerden ne kadarının verileceği (zekâtın miktarı) yani farz olan miktar tayin edilmiştir. Mekke'de ise zekât herhangi bir miktar ile sınırlanو وآتو " dırılmadan farz k1lınmıştır. Bu durum yine ( Mekkî olan) başka bir surede

84 es-Sâffât, 37/40-42.

85 Bk. Nâsiruddin Ebu'l-Hayr Abdulah b. Ömer el-Kâdî el-Beydâvî, Envâru't-tenzîl ve esrâru't-te'vîl, 5, nşr. Muhammed Abdurrahman el-Mer'aşlî, Beyrût, Dâru ihyâi't-turâsi'l-Arabî-Müessestu't-târîhi'l-Arabî, ts., s. 9.

86 el-Mü'min,40/40.

87 el-Vâkia, 56/33.

88 Ragıp Paşa, Hâşiyetu Râgıb Paşa, vr. 365b.

89 Fussilet, 41/6-7.

90 el-Beydâvî, Envâru't-tenzîl ve esrâru't-te'vîl, 3, s. 67. 
"،... Hasat günü de hakkını (öşürünü) verin”91 şeklinde ifadesini bulmuştur. ${ }^{92}$ Râgıb Paşa böylelikle bu ayeti başka bir ayeti referans göstererek açıklamakta ve ileri sürdüğü bu görüşü onunla desteklemiş olmaktadır.

Râgıb Paşa, bu alıntıyı eş-Şihab'ın hâşiyesinden özetleyerek aldığını ${ }^{93}$ ve bu konunun Rum suresinde detaylı bir şekilde anlatıldığını belirtmektedir. Biz bu

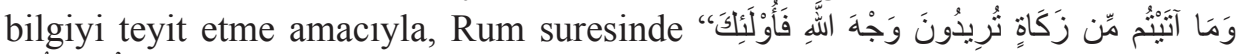
"Ama Allah’1n hoşnutluğunu isteyerek her ne zekât verirseniz; işte bunu yapanlar sevaplarını kat kat arttıranlardır"94 şeklindeki ilgili ayete yöneldiğimizde Râgıb Paşa'nın hâşiyesinde herhangi bir açıklama görmemekteyiz. Fakat alıntı yaptığı kaynağı yani Hâşiyetu'ş-Şihab'1 incelediğimizde ise, ilgili ayet kısmında detaylı bir açıklama bulunmaktadır. ${ }^{95}$ Dolayısıyla bu durum bize, Râgıb Paşa'nın bazen alıntı yaptığı bilgiyi, asıl kaynakta ifade edildiği şekilde (eş-Şihab'ın Fussilet suresinde ilgili ayet kısmındaki lafızlarla) aktardığını göstermektedir.

\subsubsection{Dilbilimsel Açılamalar}

Beydâvî tefsirinin en önemli özelliklerinden biri yapmış olduğu dilbilimsel açıklamalardır. Esasen Beydâvî tefsiri, dilbilimsel tefsirin, özellikle de beyan, bedi' ve belagatin en güzel örneklerinin bulunduğu Keş̧̧af' 'n çizgisinde bir tefsir olması hasebiyle o da bu yönü öne çıkarmıştır. ${ }^{96}$

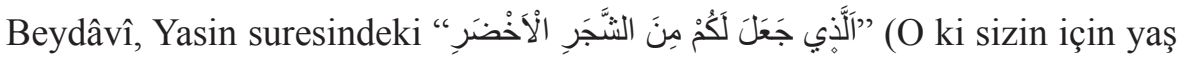
"من الثجر الأخضر "(merh ve/veya afar) ağacından ateş çıkarır) ("عaş ağaç) ibaresinin "على المعنى" (mana esas alındığında) diyerek ahdar kelimesinin müennes hali olan hadra ile " takdirinde olduğunu ifade etmektedir. ${ }^{98}$ Râgıb Paşa burada musannifin " kelimesi ile ne tür bir bilgi kastettiğini şu şekilde vuzuha kavuşturmaktadır: "الثجر" ismi lafzen müzekker, manen çoğul isim olduğu için müennestir; aynen "ثمر ثمرة" (semera, semer) kelimesinde olduğu gibi. Bu kelime yani şecer kelimesi "شجرة" (şecera) kelime-

91 el-En‘am,6/141.

92 Ragıp Paşa, Hâş̧iyetu Râgıb Paşa, vr. 459b.

93 Bk. Şihabuddin Hafâcî, Hâşiyetu'ş-Şihâb el-müsemmâ İnâyetu'l-Kâdî ve kifâyetu'r-râdî alâ tefsiri'l-Beydâvî, 7, Beyrût, Dâru Sadır, ts., s. 388-389.

94 er-Rûm, 30/38.

95 Hafâcî, Hâşiyetu'ş-Şihâb, 7, s. 123-124.

96 Bk. Süleyman Gür, "Kâzî Beyzâvî Tefsirinde Belagat İlmi ve Uygulanışı”, (Yayımlanmamış Doktora Tezi), Atatürk Üniversitesi, Erzurum, 2014, s. 44-338.

97 Yâsîn, 36/80.

98 el-Beydâvî, Envâru't-tenzîl ve esrâru't-te'vîl, 4, s. 2754. 
sinin çoğuludur. Bu ve benzeri isimler bazen lafzına bazen de manasına hamledi-

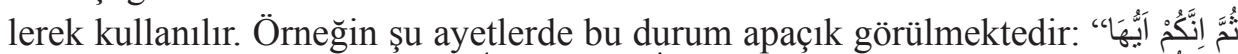

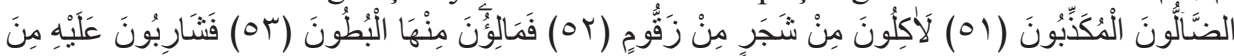
99،“و (Sonra siz ey haktan sapan yalanlayicilar! Mutlaka (cehennemde) bir ağaçtan, zakkumdan yiyeceksiniz. Karınlarınızı ondan dolduracaksınız. Üstüne de o kaynar sudan içeceksiniz). Bu ayette " "عليه" "şeklinde gelen her iki zamir de "شجر" kelimesine racidir. Birincisinde zamir şecer kelimesinin lafz1 esas alınarak müzekker, ikicisinde ise manası esas alınarak müennes kııınmıştır. ${ }^{100}$

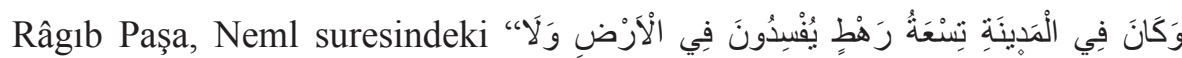
يُصْنِحُونَ" (Şehirde dokuz kişilik bir çete vard1. Bunlar yeryüzünde bozgunculuk

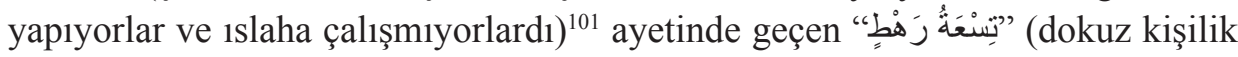
çete) cümlesinin irabı ile alakalı şu nahvî bilgileri kaydetmektedir: "Nahvî bir kural gereği üçten ona kadar olan sayıların temyizleri cemi`/çoğul olarak gelir. " ") (raht) kelimesi lafzen müfret olduğu halde burada dokuz sayısının temyizi olarak gelmiştir; çünkü -musannifin de ifade ettiği gibi- bu kelime müennes olan "cemaat" manası taşımaktadır. Dolayısıyla sanki bu ayette "نسعة أنفس" (Dokuz nefis) denilmektedir." 102

Râgıb Paşa müfessirin dilbilimsel tahlilleri bağlamında mukaddimesinde kullandığ1 "فكثف عنهم قناع الانغلاق" (onlar görsünler diye muhkem ayetleri üzerindeki kapalı peçeyi açtı) ${ }^{103}$ cümlesini açıklarken: "Burada istiare-i mekniyye ve tahyîliyye vardır. Kapalı olan kelam, örtülü/peçeli olan bir kadına benzetilmiştir. Müşebbehun bih (kadın) hazfedilerek onun levazımı olan peçenin zikredilmesi ile ona işaret edilmiştir"104 diyerek belâğî bir duruma işaret etmiştir.

Beydâvî, (namazlarını kılarlar) anlamında "ويقيمون الصلاة" şeklinde geçen Bakara suresi 3. ayetiyle alakalı dört mana zikretmektedir. ${ }^{105}$ Râgıb Paşa zikredilen bu dört mananın ilk ikisinde yani "يعدّلّون أركانها أو يو اظبون عليه" (onun rükünlerini muntazaman bir şekilde yerine getiriyorlar veya o namaza devam ediyorlar) cümlelerinde istiâre-i tebe "iyye olduğunu, ${ }^{106}$ üçüncüsünde "يتشمرون لأدائها" (onu

99 el-Vâkia, 56/51-54.

100 Ragıp Paşa, Hâşsiyetu Râgıb Paşa, vr.432 b. Benzeri etimolojik örnekler için bk. vr. 454b, 457a, 463a.

101 En-Neml, 27/48.

102 Ragıp Paşa, Hâş̧iyetu Râgıb Paşa, vr. 383a. Benzeri nahvî örnekler için bk. vr. 8b, 9b, 10a, 345a, 422b, 439a, 440a, 475b.

103 el-Beydâvî, Envâru't-tenzîl ve esrâru't-te'vîl, 1, s. 23.

104 Ragıp Paşa, Hâşsiyetu Râgıb Paşa, vr. Mukaddime.

105 Bk. el-Beydâvî, Envâru't-tenzîl ve esrâru't-te'vîl, 1, s. 38.

106 İstiâre-i tebe'iyye: Musteâr (kendisinde istiâre yapılan kelime), müştak, ism-i zaman ve mekân, 
eda etmek için hazırlanıyorlar) cümlesinde mecaz-1 mursel (kolları sıvamak), ${ }^{107}$ dördüncüsünde "يؤدونها" (eda ediyorlar) cümlesinde ise, mecaz olmayıp kinaye ${ }^{108}$ olduğunu söylemektedir. ${ }^{109}$

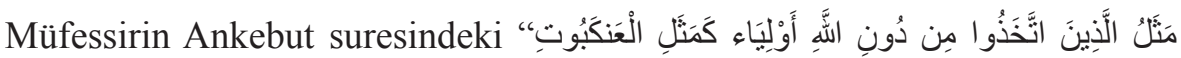

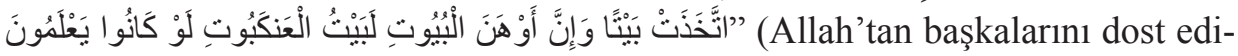
nenlerin durumu, kendine bir ev edinen örümceğin durumu gibidir. Evlerin en dayanıksızı ise şüphesiz örümcek evidir. Keşke bilselerdi!) ${ }^{110}$ ayetinin tefsirinde kullandığ1 "فيما اتخذوه معتمدا ومتكلو" (Oray1 sığınak edinmeleri...) ${ }^{111}$ cümlesine

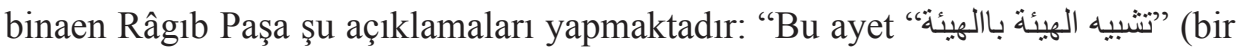
sureti başka bir surete benzetmek) kabilindendir. Şöyle ki; putları dost edinip onlara ibadet eden ve onlardan menfaat umarak onlara itimat eden kimsenin hali, kendisini ne sıcak ne soğuk ne de yağmur ve eziyetten koruyan -kısacası normal bir evden beklenilen hiçbir menfaati sağlamayan- bir yuva/ev edinen örümceğin haline benzetilmiştir. Biz deriz ki, 'bu ayet "تثبيه المركب بالمركب" (teşbîhu'l-murekkebi bi'l-murekkeb) ${ }^{112}$ kabilindendir; çünkü her iki tarafın da bir sığınağı ve ona itimad1 söz konusudur." 113

ism-i alet, fiil, isim fiil veya edatlardan biri ile yapılan istiâre çeşidine denir. (Bk. Ebû Ya'kûb Yusuf b. Ebibekir Muhammed b. Ali es-Sekkâkî, Miftâhu'l-ulum, nşr. Naim Zerzûr, 2. bs., Beyrût, Dâru'l-kutubi'-ilmiyye, 14071987/, s. 369-380; es-Seyyid Ahmed el-Hâşimî, Cevâhiru'l-belâga, nşr. Yusuf es-Somaylî, Beyrût, el-Mektebetu'l-asriyye, ts., s. 264; Nusreddin Bolelli, Belâgât Beyan-Meânî-Bedi ' İlimleri Arap Edebiyatı, İstanbul, Marmara Üniversitesi İlahiyat Fakültesi Vakfi Yayınları, 2015, s. 94.

107 Mecaz-1 mürsel: Muşâbehetin dışında gözetilen bir alakadan dolayı aslî mananın kastedilmediğine delalet eden bir karine ile birlikte kasıtlı olarak aslî manası dışında kullanılan kelimedir. Hakiki mananın kullanılmasına mani olan bu karine, lafziyye veya hâliyye olabilir. Bk. es-Sekkâkî, Miftâhu'l-ulum, s. 356-369; el-Hâşimî, Cevâhiru'l-belâga, s. 252; Bolelli, Belâgât Beyan-Meânî-Bedi ' Ilimleri Arap Edebiyatı, s. 126.

108 Kinâye: Aslî mananın anlaşılmasına mâni bir karine olmamakla birlikte onun dışında başka bir mana kastedilerek kullanılan lafza denir. Veya kinaye, sözü üstü kapalı/dolaylı şekilde kullanma sanatına denir. Bk. el-Hâşimî, Cevâhiru'l-belâga, s. 287-288; Bolelli, Belâgât Beyan-Meânî-Bedi' Ilimleri Arap Edebiyatı, s. 147.

109 Ragıp Paşa, Hâşiyetu Râgıb Paşa, vr. 8b.

110 el-Ankebût, 29/41.

111 el-Beydâvî, Envâru't-tenzîl ve esrâru't-te'vîl, 4, s. 195.

112 et-Teşbîhu'l-murekkep/Teşbîhu't-temsîl: Benzetme yönü birbiri ile sık1 bağlantısı olan iki veya daha fazla unsurdan meydana gelen itibari/hayali teşbihe 'temsilî teşbih' denir. Öyle ki bu unsurlardan bir tanesi cümleden çıkarılsa mütekellimin teşbihten kastı kaybolur. Bk. el-Hâşimî, Cevâhiru’l-belâga, s. 223; Bolelli, Belâgât Beyan-Meânî-Bedi 'Ilimleri Arap Edebiyatı, s. 53.

113 Ragıp Paşa, Hâş̧iyetu Râgıb Paşa, vr. 396b. 


\subsubsection{Beydâvî’nin Beyanlarına Yönelik Açıklama ve Eleştirileri}

Râgıb Paşa, çoğunlukla Beydâvî’nin tefsirindeki beyanları takdir edip ondaki açıklamalara katılıyorken, az da olsa bu yöndeki yorumlarını eleştirdiği olmuştur.

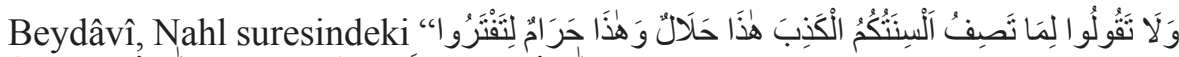

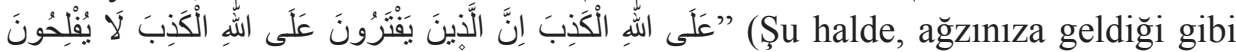
yalan-yanlış konuşarak, "Bu helaldir, şu haramdır." demeyin. Aksi takdirde, kendi kafanıza göre uydurduğunuz hükümleri Allah'a yalan isnat etmiş olursunuz. (Unutmayın ki) kendi yalanlarını/uydurma hükümlerini Allah'a isnat edenler asla onmaz, iflah olmazlar) ${ }^{114}$ ayeti tefsir ederken oradaki lâm harfinin türünü belirtmek sadedinde, "تعليل لا يتضمن الغرض" (İçinde amaç/maksat barındırmayan bir ta 'lîl lâmıdır)"115 ifadesini kullanmaktadır. Râgıb Paşa müfessirin bu cümledeki meramını/maksadını Şeyhzâde Hâşiyesi'ndeki ifadeleri ${ }^{116}$ aynen kullanarak şu şekilde açıklamakta ve ona itiraz etmektedir: Bu fiildeki lâm harfi, ta'lîl (sebep bildirmek) için değildir, (Allah'a yalan uydurmak için, 'şu helâldir', 'şu haramdır' demeyin. Şüphesiz, Allah'a yalan uyduranlar, kurtuluşa eremezler) ayetini tefsir ederken ayetteki litefterû (yalan uydurmuş olursunuz) fiilindeki lâm, âkıbet/sonuç ve sayrûre ifade etmek için gelmiştir; çünkü onlar mesnetsiz olarak "bu helaldir, şu haramdır" şeklinde kalıba döktükleri bu cümlelerinde Allah'a iftirayı amaçlamamışlardır. Bilakis onlar helal ve haram kılma işini, "Bize bunu Allah emretti" diyerek Allah'a isnat etmişlerdir. Fakat sarf ettikleri bu sözler, onları Allah'a iftira atmaya kadar götürmüştür. Nitekim ayetin devamında Allah, müfterilere, "kendi uydurma hükümlerini Allah'a isnat edenler asla iflah olmaz." şeklinde tehditte bulunmuştur. ${ }^{117}$

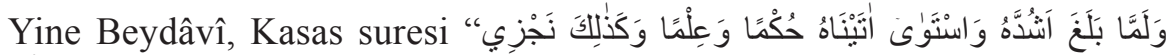
الُْحْحَسنِينَ (Mûsâ, olgunluk çağına ulaşıp gelişimini tamamlayınca, biz ona ilim ve hikmet verdik. Biz, iyilik edenleri böyle mükâfatlandırırız) ${ }^{118}$ ayetinin tefsirinde " "حُكْمَ" ile kastedilenin, nübüvvet veya hikmet ehlinin bilgisi olduğunu belirtmektedir. ${ }^{119}$

114 en-Nahl, 16/116.

115 el-Beydâvî, Envâru't-tenzîl ve esrâru't-te'vîl, 3, s. 243.

116 Bk. Muhammed b. Muslihuddin Mustafa el-Kocevî el-Hanefî Şeyhzâde, Hâşsiyetu Muhyiddîn Şeyhzâde alâ tefsîri'l-Kâdî el-Beydâvî, nşr. Muhammed Abdulkadir Şâhîn, 5, Beyrût, Dâru'lkutubi'l-ilmiyye, 1419/1999, s. 338.

117 Ragıp Paşa, Hâşiyetu Râgıb Paşa, vr. 289a. Benzeri örnekler için bk. vr. 1a, 2b, 427a, 495a.

118 el-Kasas, 28/14.

119 el-Beydâvî, Envâru't-tenzîl ve esrâru't-te'vîl, 4, s. 173. 
Râg1b Paşa burada Şihab el-Hafâcî’nin ibaresini aynen vererek

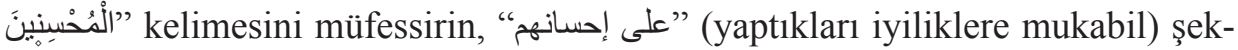
linde tefsir etmesinden ötürü " "حُكْ" kelimesi ile kastedilenin nübüvvet/peygamberlik olamayacağına dikkat çekmektedir; zira peygamberliğin herhangi bir amelin karş1lı̆̆ olarak verilemeyeceğini ifade ederek ikinci ihtimalden yana bir tercih kullanmaktadır. ${ }^{121}$

\subsubsection{Fıkhî Açıklamaları}

Tefsirlerde fikhî meseleler oldukça önem arz etmektedir. Tamamıyla fikhî konulara hasredilmiş pek özel tefsir yazılmıştır. Ahkâmu'l-Kur'an dediğimiz bu tür eserler hicrî ikinci-üçüncü asırlara gidecek kadar eskidir. ${ }^{122}$ Ahkâm türünden olmayan tefsirlerde de fikhî konulara değinilmektedir. Râgıb Paşa'nın üzerine hâşiye yazmış olduğu Kâdî Beydâvî tefsirinde de zaman zaman bazı fikhî konular işlenmiştir. Beydâvî, Şâfiî mezhebine mensup olduğu için, açıklamalarını bu mezhebin esas ve ilkelerine göre yapmıştır. Hanefî mezhebine mensup olan Râgıb Paşa ise, bu yerlerde Hanefî mezhebinin prensiplerine göre yorumlar yapmıştır. Bunları da Hanefi mezhebini kast ederek "واما عندنا" (bize göre) ifadesini kullanarak yapmıştır. ${ }^{123}$

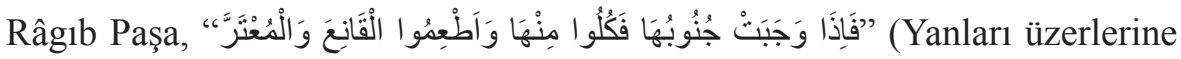
düşüp canları çıkınca onlardan siz de yiyin, istemeyen fakire de istemek zorunda kalan fakire de yedirin) ${ }^{124}$ ayetiyle ilgili “"قال في التيسير" diyerek Ebû Hafs en-Nesefî’nin tefsirinden ${ }^{125}$ şu fikhî hükümlerden bahsetmektedir: "Bu ayetteki 'yeme ve yedirme' fiilleri emir manasında olmayıp bilakis ibâha anlamı taşımaktadır. Bir kimsenin hac ibadeti için kestiği kurbandan yemesi veya yememesi de caizdir. Şayet kişi kurbanının tamamını kendisi için ayırmış olsa da herhangi bir tazminde bulunması gerekmez. Bu hüküm [sadece hac ibadeti için kesilen kurbanlarla ilgili olmayıp], kurban ibadeti için kesilen bütün hayvanlar hakkında geçerlidir. Fakat kefâret için kesilen kurbanların tamamı fukaraya tasadduk edilmesi gerekir.

120 Bk. Hafâcî, Hâşiyetu'ş-Şihâb, 7, s. 67.

121 Ragıp Paşa, Hâşiyetu Râgıb Paşa, vr. 387a.

122 Bk. Mevla el-Hasen b. el-Hüseyin b. el-Hayyân, “Ahkâmu'l-Kur'ân İlmi: Doğuşu, Gelişimi ve Eserleri Üzerine Bir Araştırma”, trc. Mustafa Şentürk-Mine Özer-Narin Yavuz, İslam Hukuku Araştırmaları Dergisi, 22, 2013, s. 457-491.

123 Bk. Mollabirahimoğlu, Koca Râgıb Mehmed Paşa ve Hâş̧iye 'Alâ Tefsiri'l-Kâdî el-Beydâvî Adlı Eserin Tahlîli, s. 144.

124 El-Hac, 22/36.

125 Necmuddin Ömer b. Muhammed Ebû Hafs en-Nesefî, Et-Teysîr fi 't-tefsîr, 10, thk. Mahir Edib Habbûş, İstanbul, Dâru'l-lübâb, 14402019/, s. 503. 
Kendisinin bu hayvandan yediği veya bir zengine hediye ettiği kısım için bedel ödemesi gerekir."

Ragıb Paşa, el-Merğînânî'nin el-Hidâye adlı kitabından ${ }^{126}$ da şunu nakletmektedir: "Nafile, temettü' ve kırân haccı için kesilen hedy/kurbanlardan kişinin yemesi ve aynı şekilde onlardan -örfte maruf olduğu üzere- tasadduk etmesi de müstehaptır. Bu durum, ayette emir kipi olarak gelen iki fiilden kastedilen mananın ibâha olduğuna delalet etmektedir" denilmektedir." ${ }^{127}$

Görüldüğü üzere Ragıb Paşa, yukarıda da belirttiğimiz üzere ahkâm ile ilgili hususlarda tefsirine hâşiye yazdığı Beydâvî' den farklı düşünmüştür. Beydâvî, tefsirinde birçok ahkâm ayetini mensubu olduğu Şafîi mezhebi doğrultusunda açıklamıştır. Râgıb Paşa ise, buna Hanefî mezhebine ait hükümleri ilave etmiş ve kendi mezhebinin görüşünün daha isabetli olduğunu belirtmiştir. Zaman zaman Beydâvi'nin değinmediği bir konuyu fikıh literatüründen yararlanarak detaylıca mevzubahis etmiştir. Yine müfessirin birtakım cümlelerinin bazı mukadder fikhî suallere cevap teşkil ettiğini belirterek bu sualleri dile getirmeye özen göstermiştir. ${ }^{128}$

\subsubsection{Kelâmî Açıklamaları}

Dirâyet tefsirlerinde en fazla üzerinde durulan hususlardan biri kelâmî konulardır. Râgıb Paşa'nın üzerine hâşiye yazdığı Beydâvî Tefsiri de, bir dirâyet tefsiri olması hasebiyle kelâmî konulara bolca yer vermektedir. Esasen bu tefsir, Mutezile mezhebine mensup olan ve kelâmî konuları bu mezhebe göre açıklayan Zemahşerî’nin (v. 538/1144) Keşşaf adlı tefsirindeki kelâmî görüş ve iddialarına cevap olmak üzere yazılmıştır. ${ }^{129}$ Beydâvî ve Râgıb Paşa, bunların her ikisi de Ehl-i Sünnet'e mensup olmaları itibariyle kelâmî-itikâdî konularda aralarında fazla görüş ayrılığg yoktur. Bu yüzden de Râgıb Paşa ekseriyetle Beydâvî'yi destekler ve teyid eder mahiyette açıklamalar yapmaktadır. ${ }^{130}$

126 Bk. Burhanuddin Ebu'l-Hasan Ali b. Ebibekir el-Merğinânî, el-Hidâye şerhu bidâyeti'l-mübtể maa şerhi Abdilhayy el-Leknevî, 2, nşr. Nuaym Eşref Nûr Ahmed, Pakistan, İdâretu'l-Kur'ân ve'l-ulûmi'l-İslâmiyye, 1417, s. 490-492.

127 Ragıp Paşa, Hâş̧iyetu Râgıb Paşa, vr. 342b. Benzeri fikhî örnekler için bk. vr. 380b, 400b, 414a, 499a, 510b, 512b.

128 Mollaibrahimoğlu, Koca Râgıb Mehmed Paşa ve Hâş̧iye 'Alâ Tefsiri'l-Kâdî el-Beydâvî Adlı Eserin Tahlîli, s. 144-149.

129 Bk. Muhammed Abdurrahman el-Mer'aşlî, "Mukaddime”, Envâru't-tenzîl ve esrâru 't-te'vîl, 1, nşr. Muhammed Abdurrahman el-Mer'aşlî, Beyrût, Dâru ihyâi’t-turâsi'l-Arabî-Müessestu'ttârîhi'l-Arabî, ts., s. 12-14.

130 Mollabirahimoğlu, Koca Râgıb Mehmed Paşa ve Hâşiye 'Alâ Tefsiri'l-Kâdî el-Beydâvî Adlı Eserin Tahlîli, s. 149. 


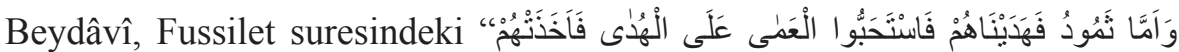

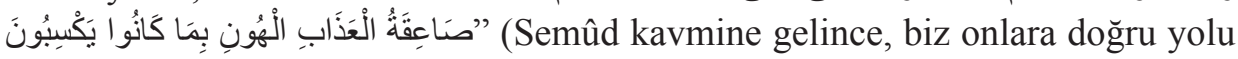
göstermiştik. Ama onlar körlüğü hidayete tercih etmişler ve yaptıklarına karşı1ık, alçaltıcı azap yıldırımı onları çarpmışt1) ${ }^{131}$ şeklindeki ayeti, "Biz, delilleri gözlerinin önüne sererek ve peygamberler göndererek onlara hakkı/doğru yolu gösterdik. Fakat onlarsa hidayete karşı dalâleti tercih ettiler" 132 şeklinde tefsir etmektedir.

Râgıb Paşa müfessir Beydâvî’nin bu cümlelerine ilaveten şu açıklamaları getirmektedir: "Mu'tezile bu ayeti delil alarak iman ve küfrün (Allah'in dilemesinden, kudretinden) bağımsız olarak salt kulun ihtiyarı ile gerçekleştiğini iddia etmektedir. Çünkü (onlara göre) Allah Teâlâ’nın “فَ" (Onlara hidayeti/doğru yolu gösterdik) ifadesi (hidayet için gerekli olan) delillerin önlerine sunulmasına

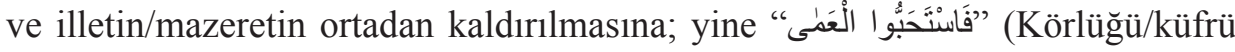
sevdiler/tercih ettiler) sözü de, onların küfrü bizzat kendilerinin tercih ettiğine işaret etmektedir. Onların bu iddialarına karşı şöyle bir reddiye yapılmaktadır: Ayette geçen (الاستحباب) (Sevgi/tercih) lafzı bu konuda asıl müessir/etkenin Allah Teâlâ'nın kudreti olduğunu, fakat bununla birlikte kulun da bunda bir rolü/dahli bulunduğunu ${ }^{133}$ ihsas etmektedir. Çünkü muhabbet ihtiyari bir eylem olmayıp esrarengiz/garip (من الدقائق العجيبة) bir durumdur ve İmam Beydâvî de burada ona işaret etmektedir. Muhabbetin ihtiyârî bir eylem olmayışının anlamına gelince onun -oluşabilmesi için gerekli olan ihtiyârî eylemler takdim edildikten sonra-, (mizacın cezbesiyle/ruhların birbirleriyle uyuşmasıyla tezahür/tahakkuk etmesidir. Burada kişinin, kalbinin sevdiğine doğru meyletmesi

131 Fussilet, 41/17.

132 el-Beydâvî, Envâru't-tenzîl ve esrâru't-te'vîl, 5, s. 69.

133 Râgıb Paşa, bu bilgiyi eş-Şihab'ın hâşiyesinden telhis yaparak yazdığını bildirmektedir. Bu

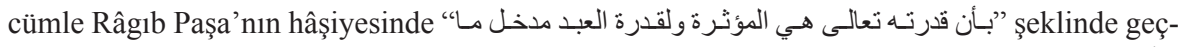

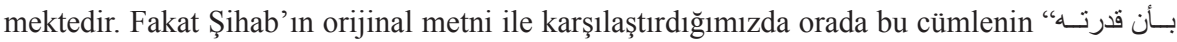

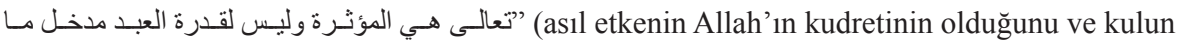
kudretinin herhangi bir dahli/etkisi olmadığını...) şeklinde anlamı olumsuzlaştıracak bir kelime "ليس" ilavesiyle yazıldığını tespit etmekteyiz. Biz elimizdeki Şihab'ın hâş̧iye metnini -her hangi bir baskı hatası olma ihtimalinden emin olmak için- başka bir nüsha ile karşılaştırdığ1mızda orada da aynı şekilde yazıldığını müşahede etmekteyiz. Fakat başka bir hâşiyede (Paşa'nın âdeten kaynak olarak kullandığı 'Hâşiyetu Şeyhzâde'de) bu cümlenin nasıl yazıldığını kontrol ettiğimizde, cümlenin Paşa'nın yazdığı şekilde (olumlu bir cümle olarak) yazıldığını görmekteyiz. Yani, Şihab'a göre muhabbetin husulünde müessir olan şey, Allah ve kulun kudretinin muhassalası/bileşkesidir. Bu durum bize Paşa'nın böyle bir tasarrufu bilinçli yaptı̆̆ını ihsas ettirmektedir. Krş. El-Hafâcî, Hâş̧iyetu'ş-Şihâb, 7, s. 394; Muhyiddin Şeyhzâde, Hâşiyetu Muhyiddin Şeyhzâde ale 'l-Beydâvî, 7, 2. bs., Beyrut, Dâru'l-kutubi'l-ilmiyye, 2013, s. 344. 
hususunda herhangi bir ihtiyâr1/tercihi söz konusu değildir. Lakin muhabbet, mukeddemat1 -gerçekleşmesi için öncesinde takdim edilenler- itibariyle de ihtiyârî bir durum arz etmektedir. ${ }^{134}$

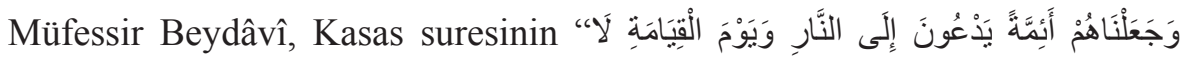
"يُنصَرُونَ" (Biz onları, ateşe çağıran öncüler kıldık. Kıyamet günü de kendilerine yardım edilmeyecektir) 41 . ayetiyle ilgili şu tefsirî bilgileri kaydetmektedir: " $\mathrm{Bu}$ ayet, '(Biz onları) sapkınlar için örnek yaptık' anlamındadır. Yine denilmiştir ki buradaki (جعل) (kılmak) fiili, tesmiye/isimlendirme için yahut da onları bundan uzaklaştıracak lütfu men etme anlamında kullanılmıştır." ${ }^{135}$

Râgıb Paşa, müfessir Beydâvî’nin bu sözlerini pekiştirecek şeklide şunlar1 ilave etmektedir: "Ehl-i Sünnet mezhebine göre -bu ayet delil gösterilerek-, (جعل) fiili, (خaratmak) fiilinin anlamını taşımaktadır; çünkü kulların hayır ve şerden müteşekkil olan bütün fiilleri, Allah'ın yaratması dâhilindedir. Mu'tezile mezhebi ise (جعل) kelimesini bazen tesmiye olarak bazen de Allah'ın onları hidayete ulaştırmaması ve onlardan bu lütfu men etmesi şeklinde tevil etmektedir. Ayrıca Râgıb Paşa, Müfessirin bu görüşe (قيل) lafzı ile işaret etmesinin, dolaylı yoldan Zemahşeri'ye de bir reddiye olduğunu ifade etmektedir. ${ }^{136}$

\subsubsection{6. İ‘câzu'l-Kur'ân ve Esrâru'l-Kur'ân Hakkındaki Beyânları}

İ'câzu'l-Kur'ân konusu, Kur'ân'ın lafız, ibare, mana ve maksatlarında erişilmez bir noktada olduğunu gösteren bir ilimdir. ${ }^{137}$ Öteden beri münhasıran bu konuya tahsis edilmiş çok sayıda müstakil eser yazılmıştır. Râgıb Paşa'nın hâşiyesini yaptığı Beydâvî tefsiri gibi dirâyet ve belağât yönü öne çıkan eserlerde de bu konu üzerinde durulmuştur.

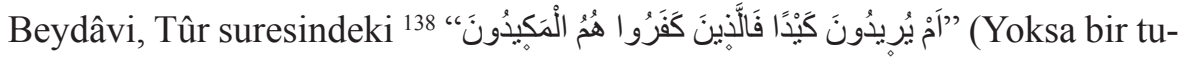
zak mı kurmak istiyorlar? Asıl, inkâr edenler tuzağa düşecek olanlardır) ayetini, "kâfirler, Daru'n-Nedve'de Rasulullah'a tuzak kurmuşlardır. Fakat bu kurdukları tuzağa Bedir günü kendileri düşmüş ve orada ölmüşlerdir" şeklinde tefsir etmektedir. ${ }^{139}$

134 Ragıp Paşa, Hâşiyetu Râgıb Paşa, vr. 461a. Benzeri kelâmî örnekler için bk. vr. 495a, 496b, 498b, 508b, 533a, 538a.

135 el-Beydâvî, Envâru't-tenzîl ve esrâru't-te'vîl, 4, s. 179.

136 Ragıp Paşa, Hâşiyetu Râgıb Paşa, vr. 389b. Ayrıca bk. Şeyhzâde, Hâşiyetu Muhyiddîn Şeyhzâde alâ tefsîri'l-Kâdî el-Beydâvî, 6, s. 453; el-Hafâcî, Hâşiyetu'ş-Şihâb, 7, s. 75-76.

137 Bk. Yusuf Şevki Yavuz, “İ'câzü'l-Kur'ân”, 21, Türkiye Diyanet Vakfi İslam Ansiklopedisi, İstanbul, Türkiye Diyanet Vakfı Yayınları, 2000, s. 403-406.

138 et-Tûr, 52/42.

139 el-Beydâvî, Envâru't-tenzîl ve esrâru't-te'vîl, 5, s. 155-156. 
Râgıb Paşa, Bedir gazvesinin nübüvvetin onbeşinci yılında gerçekleştiğini belirtikten sonra "قيل” (denilmiştir ki) lafzı ile Şihab'ın hâşiyesinde de aynen geçen ${ }^{140}$ şöyle bir görüş nakletmektedir: Bu surede "llo" (yoksa) kelimesinin tam onbeş kez tekrarlanması bu olaya işaret etmektedir. Bu ve benzeri durumlar -her ne kadar aralarındaki münasebet gizli de olsa- Kur'ânî mu'cize'den uzak olmadığını göstermektedir. ${ }^{141}$

Buradan, Mekke'de erken dönemde inmiş olan bu ayetlerde (أح) kelimesin onbeş kez geçmiş olması, peygamberliğin onbeşinci yılında Medine döneminde gerçekleşecek olan Bedir savaşında onların tuzağa düşeceğini haber veriyor demektir, bu da gelecekte vuku bulacak bir hâdiseye atıfta bulunmuş olması itibariyle Kur'an'ın gaybî i’câzına bir örnek olarak düşünülebilir.

Yine Ragıb Paşa, Nâs suresinin tefsiriyle ilgili gerekli açıklamaları yaptıktan sonra "ثم إنه قيل (sonra denilmiştir ki) diyerek Şihab'ın hâşiyesinde geçen ifadelerin aynısıyla ${ }^{142}$ şunları aktarmaktadır: Bu surenin harf sayısı -tekrar edilenler hariç-, yirmi iki tanedir. Aynı şekilde Fâtiha suresinin harf sayısı da bu kadardır. Bu, Kur'ân'ın indirildiği senelerin sayısına tekabül etmektedir ki bu da eşsiz bir sırdır. ${ }^{143}$ Henüz Kur'an'ın nüzulü devam etmekteyken ve ne zaman biteceği bilinmezken daha sonra Mushaf haline getirildiğinde en başında ve en sonunda yer alacak olan bu iki surenin her birinin harf sayısının tekrarsız olarak 22 tane olması ile Kur'an'ın nüzul süresinin 22 yıl olması arasında bir irtibat kurulmuş, bunların Kur'an'ın nüzul süresine işaret ettiğini gösterdiği düşünülmüştür ki bu da gelecekte olacak bir duruma matuf olması hasebiyle bir mucize olarak düşünülebilir.

Öte yandan Ragıb Paşa, yine Şihab'dan nakille Kur'ân'ın ilk harfinin bâ, sonuncusunun da sîn olmasının ve bunun da Farsça'dan Arapçaya geçmiş olan " بس (bunun dışındaki her şey için bu Kitap kâfidir)" manasına geldiğine dikkat

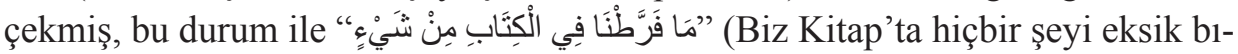
rakmadık) $)^{144}$ ayeti arasında bir ilişki kurmuş, bunu da Kur'an'ın sırlarından bir sır olarak değerlendirmiş̧tir. Yine o bu konuda şöyle diyor: Kur'an'da buna benzer rumuzlar çoktur. Fakat bunların Allah'1n muradı olduğu söylenemez. ${ }^{145}$

140 Bk. el-Hafâcî, Hâşiyetu'ş-Şihâb, 8, s. 108.

141 Ragıp Paşa, Hâşiyetu Râgıb Paşa, vr. 496b.

142 Bk. el-Hafâcî, Hâşiyetu'ş-Şihâb, 8, s. 418.

143 Ragıp Paşa, Hâşiyetu Râgıb Paşa, vr. 564a.

144 el-En'âm, 6/38.

145 Ragıp Paşa, Hâşiyetu Râgıb Paşa, vr. 564a. 


\subsubsection{Rivâyet Yöntemiyle Tefsiri}

Âlimler Kur'an-1 Kerim'i tefsir ederken genelde Kur'an'1 Kur'an'la tefsir, sünnetle tefsir, sahabe ve tâbiûn kavliyle tefsir etmeye büyük özen göstermişlerdir. Özellikle İbn Teymiyye'nin (v. 728/1328) Mukaddime fi'usûli 't-tefsîr adlı eserinde bu noktaya dikkat çekmesiyle ${ }^{146}$ artık bu yöntem bir usul haline gelmiştir. Biz de burada Râgıb Paşa hâşiyesini buna göre incelemeye çalışacağız. Ancak Kur'an'1 Kur'an'la tefsir yöntemini, bir dirâyet yöntemi olarak kabul ettiğimiz için onu yukarıda zikretmiştik, burada rivâyet yöntemine, Kur'an'1 Sünnetle tefsir yöntemiyle başlayacağız.

\subsubsection{Kur'ân'ı Sünnetle Tefsiri}

Rivâyet yöntemiyle Kur'an tefsirinde ikinci esas, Kur'an'ın Hz. Peygamber'in söz ve filleriyle tefsiridir. Bu yöntemi de Râgıb Paşa'nın hâşiyesinde

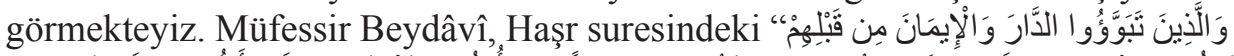

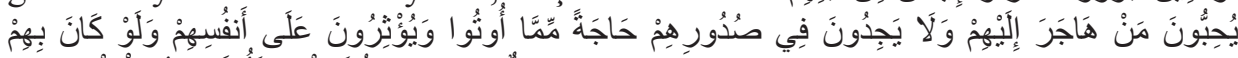

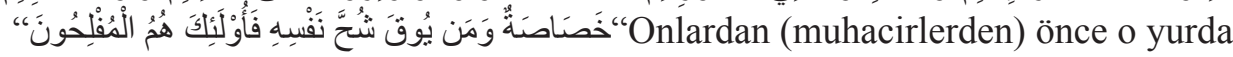
(Medine'ye) yerleşmiş ve imanı da gönüllerine yerleştirmiş olanlar, hicret edenleri severler. Onlara verilenlerden dolayı içlerinde bir rahatsızlık duymazlar. Kendileri son derece ihtiyaç içinde bulunsalar bile onları kendilerine tercih ederler. Kim nefsinin cimriliğinden, hırsından korunursa, işte onlar kurtuluşa erenlerin ta kendileridir"l147 ayetinin tefsirinde şöyle demiştir: "وقيل: سمي المدينة بالإيمان لأنها مظهر و ومصيره (Denilmiştir ki, Medine, 'İman (diyarı)' olarak isimlendirilmiştir; çünkü onun ilk olarak zuhur ettiği ve yine dönüp dolaşacağ 1 en son yer orasıdır). ${ }^{148}$ Râgıb Paşa, "müfessirin Medine'yi imanın zuhur ettiği yer olarak nitelendirmesi açıktır. Fakat "مصيره" kelimesiyle kastettiği şey, muğlak kalmıştır. Bununla

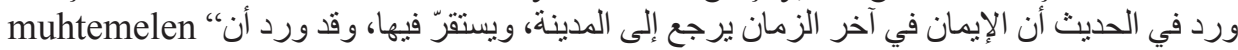
"(Hadiste vârid olmuştur ki, "Muhakkak ki iman, ahir zamanda Medine’ye dönecek ve orada yerleşecektir. Hadiste vârid olmuştur ki, "Deccal Medine'ye giremeyecektir). ${ }^{149}$ Başka bir hadiste de (İman, yılanın deliğine çekildiği/sığındığı gibi Medine'ye çekilecektir) ${ }^{150}$ şeklindeki hadislerde ifade edildiği gibi 'İmanın ahir zamanda rücu edeceği/ istikrar sağlayacağı yer, Medine'dir' gibi bir mana kastetmiştir" ${ }^{151}$ demektedir.

146 Bk. Takiyuddin Ahmed b. Abdulhalîm İbn Teymiyye, Muhamddime fì us ûli 't-tefsîr, thk. Adnan Zerzûr, 2. bs., yy., 1392/1972, s. 93-102.

147 el- Haşr, 59/9.

148 el-Beydâvî, Envâru't-tenzîl ve esrâru't-te'vîl, 3, s. 200.

149 Buhârî, Fedâilü'l-Medîne,. s9.

150 Buhârî, Fedâilü'l-Medîne,. s6.

151 Ragıp Paşa, Hâşiyetu Râgıb Paşa, vr. 513b. 
Beydâvî, "şeytanların kime ineceğini size haber vereyim mi? Onlar, her günahkâr yalancıya inerler. Bunlar da şeytanlara kulak verirler. Onların çoğu ise

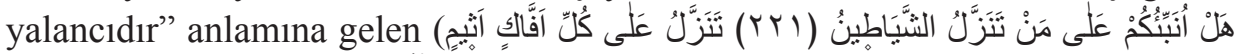

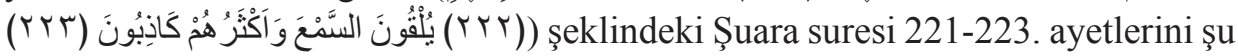
şekilde tefsir etmektedir: "O yalancılar, şeytanlara kulak verip onlardan birtakım işaretler alırlar; fakat bilgilerinin eksik olması sebebiyle muhayyileleri doğrultusunda onlara -çoğu gerçekle bağdaşmayan- birtakım eklemelerde bulunurlar. Bu durum aynen şu hadiste aktarıldığı gibidir: الكلمة يخطفها الجني فيقر ها في أذن وليه)

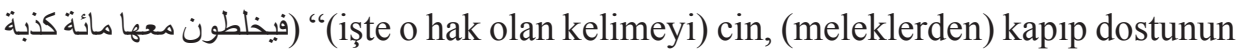
kulağına fisıldar ve onlar da ona yüz yalan ekler."152

Râgıb Paşa ${ }^{153}$ Beydâvîeenin eksik/muhtasar olarak zikrettiği bu hadisi kayna-

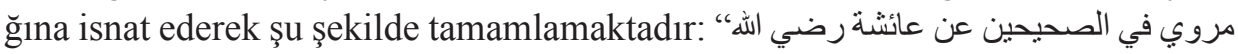

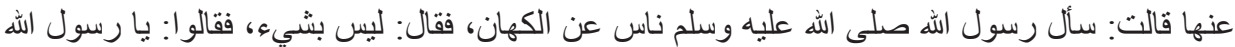

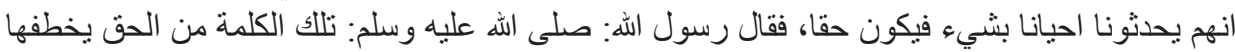
(Sahihayn'de Hz. Aişe’den rivâyet edilmiştir ki, bazı insanlar Rasûlullah'a (s.a.v.) kâhinlerin yaptıklarından sordular da Resûl-i Ekrem: "Bir şey değildir (aslı yoktur).” Dedi. "Ey Allah'ın Rasûlü! Onlar bazen geleceğe dair bazı haberler bize anlatıyorlar ve o da gerçekleşiyor" dediler. Bunun üzerine Hz. Peygamber: "Onların bu tür haberleri (görevli meleğin ilham ettiği) gerçeklerdendir. Onu cin (kâhine ulaştıran), diğer bir cinden (kendinden daha üst bir konumda olan bir cinden) kaparak dostunun (kâhin) kulağına fisıldar. Onlar da bir doğruya yüz yalan karıştırır halka sunarlar” cevabını verdi). ${ }^{154}$

\subsubsection{Kur'ân'ı Sahabe Kavliyle Tefsiri}

Rivâyet yöntemiyle tefsirin diğer bir şekli Kur'an'1 sahabeden gelen kaviller-

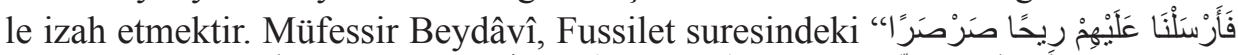
") (Biz de onlara dünya hayatında zillet azabını tattırmak için o mutsuz kara günlerde üzerlerine dondurucu bir rüzgâr gönderdik. Ahiret azâbı elbette daha rezil edicidir. Onlara yardım da edilmez) ${ }^{155}$ ayetinin tefsirinde, 'نحسات' (nehisât) kelimesi 'نحسة' (nahsetun) kelimesinin çoğuludur ve 'سعادة (saâdet) yani mutluluk, memnuniyet kelimesinin zıt anlamlısıdır. İki Hicazlı (İmam Nafi ve İbn Kesir) ve iki Basralı (Ebu Amr el Alâ ve Yakub el Hadrami) kıraat âlimleri bu kelimeyi sükun ile (نحْسات) tahfif üzere okumuşlardır. Ya da bu kelime 'فِحِ (faile) kalıbından s1-

152 el-Beydâvî, Envâru't-tenzîl ve esrâru't-te'vîl, 4, s. 152.

153 Ragıp Paşa, Hâşiyetu Râgıb Paşa, vr. 437a

154 Buhârî, Tib, s. 46; Müslim, Selam, s. 123.

155 Fussilet, 41/16. 
fat veya vasıf bildiren masdardır" 156 şeklinde bir takım etimolojik ve morfolojik açıklamalarda bulunmaktadır. Yine bu günlerin şevval ayının son günlerine denk gelen bir çarşambadan diğer bir çarşambaya kadar olan günler olduğunu ve her helak olan kavmin çarşamba günü helak olduğunu 'قيل' (denilmiştir) lafzı ile aktarmaktadır. ${ }^{157}$

Râgıb Paşa burada müfessirin bu sözlerine şu ilaveleri yapmaktadır: Müfessirin bu azap günlerinin şevval ayının son günlerinde cereyan etmiş olduğunu söylemesi ile başka kaynaklarda şubat olarak belirtilmiş olması arasında herhangi bir çelişki yoktur; çünkü el-Hâkka suresinde geleceği gibi o günler Eyyâmu'l-Acûz ${ }^{158}$ oldukları için her ikisine de tevafuk etmesi mümkündür.

Yine Râgıb Paşa, bu ayetin bazı günlerin uğursuz/kötü, bazıların ise uğurlu/ iyi olduğuna işaret ettiğini ve el-Kirmânî'nin el-Menasik adlı eserinde İbn Abbas'tan bu görüşünü destekleyen şu rivâyetin aktarıldığını belirtmektedir: " عن ابن (Ibn "عباس: الأيام كلها لله تعالى لكنه خلق بعضها سعودا وبعضها نحو سا. وقيل النحس هنا بمعنى البارد ' (Ib) Abbas'tan rivâyet edilmiştir ki, “Günlerin tamamı Allah'ındır, O’na aittir. Fakat $\mathrm{O}$, bazılarını said/uğurlu, bazılarını ise nehûs/uğursuz olarak yaratmıştır." ${ }^{159} \mathrm{Bu}-$ radaki en-nahs'tan kastedilenin soğuk olduğu da söylenmiştir.

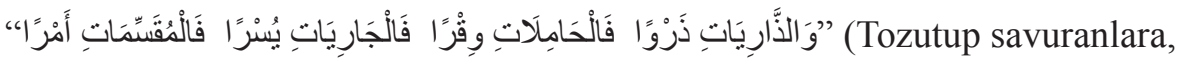
ağırlık taşıyanlara, kolaylıkla akanlara, iş bölüştürenlere andolsun ki, $)^{160}$ ayetiyle alakalı Râgıb Paşa, Hz. Ali’den nakledildiği üzere " "و "والذاريات" ayetiyle, 'rüzgârla-

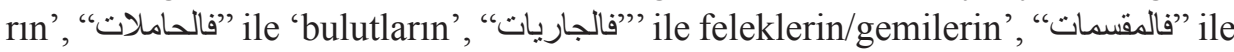
ise, 'meleklerin' kast edildiğini bildirmektedir. ${ }^{161}$ Görüldüğü üzere o, bu ayetin anlamını, sahabinin tefsiriyle tespit etmektedir.

\subsubsection{Kur'an'ı Tâbiûn Kavliyle Tefsiri}

Rivâyetle Kur'an tefsirinin bir unsuru da Kur'an'1 tâbiûn dediğimiz ve sahabenin dizinin dibinde yetişmiş olan âlimlerin sözleri ve görüşleriyle yorumlamaktır. Râgıb Paşa Hâşiyesinde bunu da hesaba katmıştır. Buna şöyle bir örnek

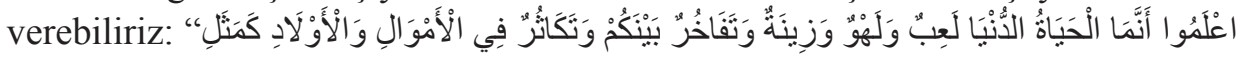

156 el-Beydâvî, Envâru 't-tenzîl ve esrâru't-te'vîl, 5, s. 69.

157 el-Beydâvî, Envâru't-tenzîl ve esrâru't-te'vîl, 5, s. 69.

158 Eyyâmu'l-Acûz: Kışın soğuğun çok şiddetli olduğu yedi güne denilmektedir. O günlerin dört tanesi Şubat ayının sonlarına, diğer üç tanesi de Mart ayının ilk günlerine tevafuk ettiği söylenir. Bk: Şihabuddin Mahmud b. Abdillah el-Huseynî el-Alusi, Ruhu'l-meânî fì tefsîri'l-Kur'ân ve 's-seb'i'l-mesânî, 12, Beyrut, Dâru'l-kutubi'l-ilmiyye, 1415, s. 365.

159 Ragıp Paşa, Hâşiyetu Râgıb Paşa, vr. 493a.

160 ez-Zâriyât, 51/1-4.

161 Ragıp Paşa, Hâşiyetu Râgıb Paşa, vr. 493a. 


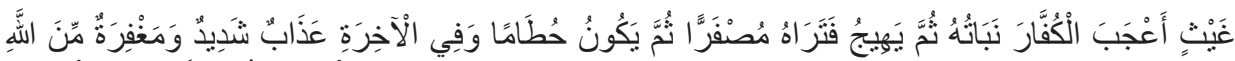

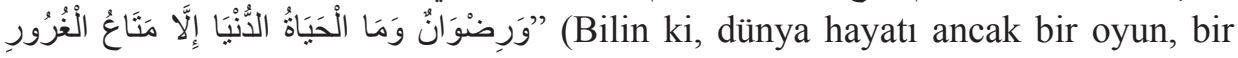
eğlence, bir süs, aranızda karşılıklı bir övünme, çok mal ve evlat sahibi olma yarışından ibarettir. (Nihayet hepsi yok olur gider). Tıpkı şöyle: Bir yağmur ki, bitirdiği bitki çiftçilerin hoşuna gider. Sonra kurumaya yüz tutar da sen onu sararmış olarak görürsün. Sonra da çer çöp olur. Ahirette ise (dünyadaki amele göre ya) çetin bir azap ve(ya) Allah'ın mağfiret ve rızası vardır. Dünya hayatı, aldanış metaindan başka bir şey değildir.) (dünyadaki fâni hayat aldatıcı bir hazdan başka bir şey değildir!) cümlesini müfessir Beydâvî, "Dünyaya yönelen ve ahireti talep etmeyen kişi için (böyledir)"163 şeklinde tefsir etmektedir.

Râgıb Paşa bu konu1da şöyel demektedir: "Müfessir bu ayetteki yorumuyla tâbiîn neslinden olan Saîd b. Cübeyr'in (ö. 90_ ₹ ) muhtemelen şu sözünü kastet-

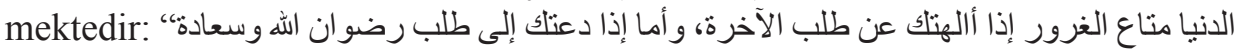
"الآخرة فنعم المتاع ونعم الوسيلة. (Dünya seni, ahireti talep etmekten al1koyduğunda aldatıc bir metadır. Fakat seni Allah'ın rizasını ve ahiret saadetini talep etmeye davet ederse/sevk ederse ne güzel bir meta ve ne güzel bir vesiledir!) ${ }^{164}$

\subsubsection{Kıraatlere Yönelik Açıklamaları}

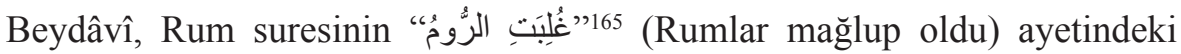

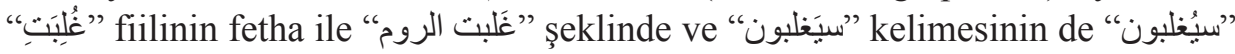
şeklinde damme ile okunduğunu haber vermektedir. (Beydâvî, Rum suresinin

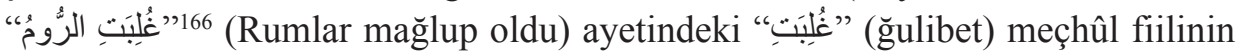

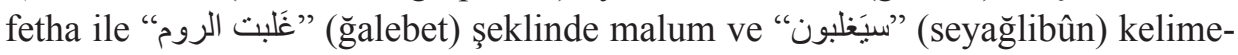
sinin de "سيُغلبون" (seyuğlebûn) şeklinde damme (meçhul sîga) ile okunduğunu haber vermektedir.) ${ }^{167}$

Râgıb Paşa, Beydâvî’nin zikrettiği bu kıraati Nasr b. Ali'nin okuduğunu ve bunun güvenilir bir şahıs olduğunu bildirdikten sonra hâşiyesine şu bilgileri eklemektedir: 'Bu kıraate, 'rivâyete/nakle muhaliftir' şeklindeki Zeccac'ın görüşü168

162 el-Hadîd, 57/20.

163 el-Beydâvî, Envâru't-tenzîl ve esrâru't-te'vîl, 5, s. 189.

164 Ragıp Paşa, Hâş̧iyetu Râgıb Paşa, vr. 508b.

165 er-Rûm, 30/2.

166 er-Rûm, 30/2.

167 el-Beydâvî, Envâru't-tenzîl ve esrâru't-te'vîl, 4, s. 201.

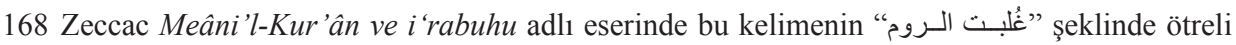
okunduğunu bildirdikten sonra Ebû Amr'ın “" غَلبت " şeklinde üstünlü okuduğunu da haber vermektedir. Fakat anlamın, kurra'nın okunuşunda icma ettiği ötreli olan okuyuşa göre olduğunu 
ile herhangi bir itiraz yapılamaz; çünkü kurranın bunun üzerinde icmâsı vardır.

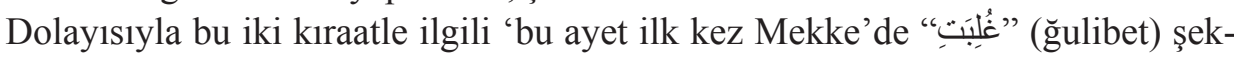
linde dammeli, ikinci kez Bedir günü " غَلبت" (ğalebet) şeklinde fethalı olarak iki defa inmiştir' şeklinde bir tevfik yapılmaktadır. Müfessirin de ifade ettiği gibi bu kıraatin anlamı; "Rumlar Rîfu'ş-Şam kırsalında Perslere karşı bir galibiyet yaşamışlardır. Bununla birlikte birkaç sene içinde Müslümanlar da onların üzerinde bir galibiyet sağlayacaklardır." şeklindedir. ${ }^{169}$

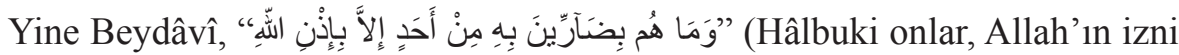

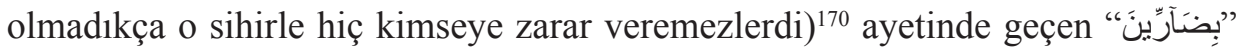
(bidârrîne) kelimesinin (bidârrî bihî min ehadin) ifadesinde geçtiği üzere “بضاري" (bidârrî) şeklinde min ehad lafzına muzaf ve araya bihî zarfı girecek şekilde izafet üzere okunduğunun bilgisini vermektedir. ${ }^{171}$ Râgıb Paşa ise burada İbn Cinnî’nin (v. 1 . r r/r q r) “bu okuyuş şaz okuyuşların en uzak olanıdır; çünkü bu okuyuşta muzâf ile muzâfun ileyh arası, zarf olan "ب̣” (bihi) ile ayrılmıştır. Ayrıca "من" (min) harf-i cerinin izafet manasını tekid etmek için araya girmiş olması da sahih değildir" görüşünü naklederek bu kıraatin uygun olmadığına dair bir izah getirmiştir. ${ }^{172}$

\subsubsection{5. İsrâiliyyât Türü Rivâyetlere Yaklaşımı}

Râgıb Paşa, İsrâiliyyâtvarî rivâyetlerde -birkaç basit bilginin dişında- genellikle müfessirin aktarımlarıyla yetinmektedir. İsrâiliyâtla ilgili şu bilgilere dikkat çekebiliriz: Ragıb Paşa, Neml suresinde 'قيل' lafzını kullanarak, Süleyman'ın (a.s.) ehl-i meşveretinin üç yüz on üç adamdan oluştuğu ve her bir kişinin on bin kişiye bedel olduklarını belirtmektedir. ${ }^{173}$

Yine Râgıb Paşa, Şihab hâşiyesinde de geçtiği üzere ${ }^{174}$ Kasas suresinin dördüncü ayetindeki "يذبح أبنائهم" (Firavun onların erkek evlatlarını boğazlıyordu) cümlesinin, mülkün/saltanatın muhafazası için erkeklerin katledilmesinin, Firavunun şeriat1/hukuku olduğuna dair bir delil teşkil ettiğini ifade etmektedir. ${ }^{175}$

belirtmektedir; zira İranlıların Romalılara galip gelerek onlara yenilgi yaşatmaları şeklinde özetlenen vakayı bu okuyuş sağlanmaktadır. Bk. Ebû İshak İbrahim b. es-Sirrî ez-Zeccâc, Meâni'l-Kur'ân ve i'râbuhu, 4, Beyrut, Âlemu'l-kutub, 1988, s. 175.

169 Ragıp Paşa, Hâşiyetu Râgıb Paşa, vr. 399a.

170 el-Bakara, 2/102.

171 el-Beydâvî, Envâru't-tenzîl ve esrâru't-te'vîl, 1, s. 98.

172 Ragıp Paşa, Hâşiyetu Râgıb Paşa, vr. 42b.

173 Ragıp Paşa, Hâşiyetu Râgıb Paşa, vr. 381a.

174 Bk. el-Hafâcî, Hâşiyetu'ş-Şihâb, 7, s. 63.

175 Ragıp Paşa, Hâşiyetu Râgıb Paşa, vr. 386a. 


\section{Sonuç}

$\mathrm{Bu}$ araştırmamız sonunda gördük ki üzerinde çalıştığımız hâşiyenin müellifi Koca Mehmed Râgıb Paşa, kuvvetli ve dirâyetli bir Osmanlı paşası ve siyaset adamı olması yanında aynı zamanda tefsir hâşiyesi yazacak kadar dinî ilimler konusunda da mahir bir kişidir. Bu eser, onun tefsir alanında yazmış olduğu ilk ve tek eserdir. Ne yazık ki Râgıb Paşa'nın yazmış olduğu bu hâşiye, ilgili alanda yeteri kadar tanınmamış, daha da ötesi Beydâvî tefsiri üzerine yazılmış olan tam hâşiyeler arasında ismi dahi zikredilmemiştir.

Bu hâşiyeyi niye yazdığına dair verdiği bilgilerden anlıyoruz ki, Ragıb Paşa bunu o günün tefsir tedrisatında kullanılması amacıyla veya büyük kalabalıklar tarafindan kullanılıp istifade edilsin diye yazmamıştır. Onun daha çok Beydâvî tefsirini mütâlaa ederken ve bu arada daha başka pek çok eserden istifade ederken kendisinde hâsıl olan kanaat ve birikimi özet bir şekilde kayda geçirmeyi arzuladığı söylenebilir. Mamafih Râgıb Paşa'nın, yer yer detaylı bilgi için başka kaynaklara yönlendirmeler yapması, ileride bu eserinin birileri tarafindan okunup istifade edilebileceğini hesaba kattığını göstermektedir.

Hâşiyenin muhtevâsı hakkında ise şu değerlendirmeleri yapmak mümkündür: Râgıb Paşa âyetleri tefsir ederken ağırlıklı olarak dirâyet yönetmine yer vermiş, bunun yanında rivâyet yöntemini de uygulamıştır. Bununla birlikte hâşiyede -birçok hâşiyede olduğu gibi- gramer ve belâğâtla ilgili açıklamaların ağırlıkla yer kapladığı müşahede edilmiştir. Yine Râgıb Paşa hâşiyesinde, garip ifadelerin îzahını, kavramların tasnifini yapmış ve Kâdî Beydâvî tarafından zikredilen hadislerin eksik kısımlarını tamamlamıştır. Kıraatlerle ilgili de bazı açıklamalar yapmış, bu tür açılamaları, sadece mütevâtir kıraatlere münhasır olmayıp yer yer şaz kıraatlerle ilgili bilgileri de kapsamıştır.

Beydâvî tefsirinde Şafiî mezhebi esasında yapılan bazı açıklamalar, Ragıb Paşa tarafından mensubu olduğu Hanefi mezhebi esas alınarak izah edilmiştir. Râgıb Paşa, müfessirin değindiği kelâmî konulardan bazılarına hâşiyesinde temas etmiştir. Ekseriyetle de bu açıklamaları, Ehl-i Sünnet'in görüşlerini destekler mahiyette yapmıştır. I'câzu'l-Kur'ân konusuna az da olsa temas etmiş, bazı örneklerle konuyu açıklamaya çalışmış, genellikle bu hususta müfessirin naklettikleri ile yetinmiştir.

Râgıb Paşa, Hâşiyesini muhtelif birkaç hâşiyeden iktibaslarda bulunarak oluşturmuş ve alıntı yaptı̆̆ kaynağı da çok sarih bir şekilde kaydetmiştir. Çoğunlukla da bu alıntılarında Şihabuddîn el-Hafâcî’nin hâşiyesini göz önünde bulundurmuştur. Onun Hâşiyesi için, “âdeta Şihabuddin el-Hafâcî'nin mutavvel olan eserinin güzel bir muhtasarıdır" denebilir. Muhtelif yerlerde yaptığımız 
karşılaştırmalar bizi böyle bir neticeye ulaştırmıştır. Bu açıdan Râgıb Paşa'nın hâşiyesinin -birkaç yeri dişında- özgün, derinlikli, orijinal ve kaynaklarından bağımsız herhangi bir bilgiyi serdetmediği söylenebilir. Oysaki siyaset, edebiyat, hukuk, uluslararası ilişkiler, askerlik gibi alanlar yanında aynı zamanda dinî ilimler alanında da yetkin olan bir kişiden, daha özgün, orijinal ve kapsamlı bir eser yazması beklenirdi. Muhtemelen idâri vazifelerinin çokluğu ve yoğun iş temposu, ayrıca yaşadığı dönemin birçok sorun ve sıkıntılarla geçmesi sebebiyle derinlikli bir eser yazmaya firsat bulamamıştır.

Bununla birlikte Hâşiyenin bir Osmanlı paşasına ait olması ve entelektüel bir ilginin ürünü olması, Beydâvî tefsiri gibi Osmanlı topraklarında son derece muteber bir tefsir üzerine yapılmış olması, ayrıca kısa ve özlü olması onu mühim kılmaktadır. Biz de bilhassa bu yönü ve ilim âlemince tanınmamış olması cihetiyle eseri incelemeyi gerekli gördük.

Çalışmayla Osmanlı tefsir kültürüne, özellikle de hâşiye liteatürüne bir nebze de olsa katkıda bulunmayı istedik. Eser, başta Şihab olmak üzere diğer eserlerle daha kapsamlı mukayeseler yapılarak da işlenebilir. Yapılmasını ümid ettiğimiz bu tür çalışmalarla Ragıb Paşa Hâşiyesinin ilim alemince daha yakından tanınması sağlanmış olacaktır. 


\section{Kaynakça}

Abay, Muhammed, "Osmanlı Döneminde Tefsir Haşiyeleri”, Başlangıçtan Günümüze Türklerin Kur'an Tefsirine Hizmetleri -Tebliğler ve Müzakereler-, İstanbul, Ensar Neşriyat, 2012.

Afyoncu, Erhan, “Kalemden Kılıca: Koca Râgıb Paşa'nın Osmanlı Bürokrasisinde Yükselişi”, Journal of Turkish Studies Türklük Bilgileri Araştırtmaları Şinasi Tekin Hatıra Sayısı I, haz. Yücel Dağl1-Yorgos Dedes-Selim S. Kuru, Boston, Harvard Üniversitesi, 2007.

Akpınar, Cemil, "İcâzet", Türkiye Diyanet Vakfi İslam Ansiklopedisi, 21, İstanbul, Türkiye Diyanet Vakfı Yayınları, 2000.

Akşit, Niyazi - Sanır, Ferruh, "Koca Ragıp Paşa", Genel Bilgi Ansiklopedisi, 851, İstanbul, Serhat Dağıtım, 1981.

Altuntaş, Halil-Şahin, Muzaffer, Kur'ân-ı Kerim Meâli, 12. bs., Ankara, Diyanet İşleri Başkanlığı Yayınları, 2011.

el-Alusi, Şihabuddin Mahmud b. Abdillah el-Huseynî, Ruhu'l-meânî fì tefsî́ri'l-Kur'ân ve's-seb 'i'l-mesânî., Beyrut, Dâru'l-kutubi'l-ilmiyye, 1415.

Aydın, Muhammed, 'Rivâyet Tefsiri Kavramı ve Kur'an'ın Kur'an ile Tefsiri: Eleştirel Bir Yaklaşım”, Sakarya Üniversitesi İlahiyat Fakültesi Dergisi, 20, 2009.

Aydıner, Mesut, "Dönemin Kaynakları ve Arşiv Belgelerine Göre Koca Râgıb Mehmed Paşa'ya Dair Bir Portre", Çukurova Üniversitesi Sosyal Bilimler Enstitüsü Dergisi, 25/4, 2016.

, "Koca Râgıb Mehmed Paşa - Hayatı ve Dönemi: 1699-1763", (Yayımlanmamış Doktora Tezi), Mimar Sinan Üniversitesi, İstanbul, 2005. , "Râgıb Paşa", Diyanet İslam Ansiklopedisi (DİA), 34, İstanbul, Türkiye Diyanet Vakfı Yayınları, 2007.

Baykal, Bekir Sttkı, "Râgıb Paşa", İslâm Ansiklopedisi, 9, İstanbul, Milli Eğitim Basımevi, 1988.

el-Beydâvî, Nâsiruddin Ebu'l-Hayr Abdulah b. Ömer el-Kâdî, Envâru't-tenzîl ve esrâru't-te'vîl, nşr. Muhammed Abdurrahman el-Mer'aşlî, Beyrût, Dâru ihyâi't-turâsi'l-Arabî-Müessestu't-târîhi'l-Arabî, ts.

Bolelli, Nusreddin, Belâgât Beyan-Meânî-Bedi` İlimleri Arap Edebiyatı, İstanbul, Marmara Üniversitesi İlahiyat Fakültesi Vakfi Yayınları, 2015.

Bursalı Mehmed Tahir, Osmanlı Müellifleri, haz. Yekta Saraç, Ankara, Türkiye Bilimler Akademisi, 2016. 
Buz, Ayhan, Sokullu'dan Damat Ferit'e Osmanlı Sadrazamlarl, 2. bs., İstanbul, Neden Kitap, 2009.

Büyük Türk Klâsikleri, "Koca Râgıb Paşa”, 6, İstanbul, Ötüken-Söğüt Yayınlar1, 1987.

Cunbur, Müjgan, "Râgıb Paşa", Türk Dünyası Edebiyatçıları Ansiklopedisi, 7, Ankara, AKM Yayıncılık, 2007.

Çelik, Ersin, "Şeyhu'l-İslam Sa'dî Çelebî ve el-Fevâidu'l-Behiyye: Hâşiye Alâ Tefsiri'l-Beyzâvî Adlı Eserinin Tahlili”, (Yayımlanmamış Yüksek Lisans Tezi), Recep Tayyip Erdoğan Üniversitesi, Rize, 2015.

Demirbağ, Ömer, "Koca Râgıb Paşa ve Dîvân-1 Râgıb”, (Yayımlanmamış Doktora Tezi), Yüzüncü Y1l Üniversitesi, Van, 1999.

ed-Duğeym, Mahmud es-Seyyid, Fihrisu'l-mahtûtâti'l-Arabiyye ve't-Turkiyye ve'l-Fârisyye fi mektebeti Râgıb Paşa, Cidde, Sekîfetu's-safa el-ilmiyye, $1437 / 2016$.

Dursun, Yasin, “Koca Râgıb Paşa'nın Arûz Risalesi Adlı Eserinin Tahkik ve Tahlili”, (Yayımlanmamış Yüksek Lisans Tezi), İstanbul Üniversitesi, İstanbul, 2014.

Göllü, Bilge Karga, "Koca Râgıb Paşa Üzerine Bir Kaynakça Denemesi”, Çukurova Üniversitesi Sosyal Bilimler Enstitüsü Dergisi, 25/4, 2016.

Gültekin, Hasan, "Koca Râgıb Paşa Münşeâtında Nâdir Şah ve Caferî Mezhebi Tartışmalarına Dair Mektuplar". Türk Kültürü ve Hacı Bektaş Velî Araştırma Dergisi, 76, 2015.

Gür, Süleyman, "Kâzî Beyzâvî Tefsirinde Belagat İlmi ve Uygulanışı”, (Yayımlanmamış Doktora Tezi), Atatürk Üniversitesi, Erzurum, 2014.

el-Habeşî, Abdullah Muhammed, Câmiu'ş-şurûh ve'l-hevâş̂ิ mu'cemun şâmilun li kutubi'l-meşrûha fi 't-turâsi'l-İslâmî ve beyânu şurûhiâ, Ebuzabî: el-Mecmau's-sakâfî, 2004.

Hafâcî, Ebu'l-Abbas Şihabuddin Ahmed b. Muhammed, Inâyetu'l-Kâdî ve kifâyetu'r-Râzî Hâşiye alâ tefsîri 'l-Beydâvî, Diyarbakır, el-Mektebetu'l-İslâmiyye, ts.

Hammer, Joseph Von, Büyük Osmanlı Tarihi, haz. Erol Kılıç-Mümin Çevik, İstanbul, Üçdal Neşriyat, ts.

el-Hâşimî, es-Seyyid Ahmed, Cevâhiru'l-belâga, nşr. Yusuf es-Somaylî, Beyrût, el-Mektebetu'l-asriyye, ts. 
Hikmet, İsmail, Koca Ragıp Paşa ve Fitnat, İstanbul, Kanaat Kütüphanesi, 1933.

el-Huseynî, Muhammed b. Murad, Silku'd-durer fî a 'yâni'l-karni's-sânî 'aşer, 3. bs., Beyrut, Dâru'l-beşâiri'l- İslamiyye-Dâru İbn Hazm, 1988.

İbn Teymiyye, Takiyuddin Ahmed b. Abdulhalîm, Muhamddime fì usûli 't-tefsîr, thk. Adnan Zerzûr, 2. bs.. yy., 1392/1972.

Karabey, Turgut, "Tarih Düşürme”, Türkiye Diyanet Vakfı Íslam Ansiklopedisi, 40, İstanbul, Türkiye Diyanet Vakfı Yayınları, 2011.

Karagöz, Mustafa, "Tefsirde Rivâyet-Dirâyet Ayrımının Ortaya Çıkışı ve Mahiyeti”, bilimnâme, 5, 2004.

Kaya, Mesut, "İslam İlimler Tarihinde Muhâkemât Geleneği: Tefsir Hâşiyeleri Merkezli Bir Deneme", İslam Araştırtmaları Dergisi, 33, 2015.

Lamartine, A. De, Sona Doğru (Türkiye Tarihi), haz. M.R. Uzmen, Tercüman 1001 Temel Eser: 43, İstanbul, Kervan Kitapç1lık, ts.

Maden, Şükrü, “Osmanlılar'da el-Keşşâf ve Envâru’t-Tenzîl Hâşiyeleri”, Türkiye Araştırmaları Literatür Dergisi, 9/18, 2011.

, "Tefsirde Hâşiye Geleneği ve Hâşiyetu Muhyiddin Şeyhzâde ‘Alâ Tefsiri'l-Kâdî el-Beyzâvî Örneği’, (Yayımlanmamış Doktora Tezi), Marmara Üniversitesi, İstanbul, 2013.

, Tefsirde Hâssiye Geleneği ve Şeyhzâde'nin Envâru't-Tenzîl Hâşiyesi, İstanbul, İSAM Yayınları, 2015.

, “Tefsirde Şerh Haşiye ve Ta'lika Lüteratürü”, Tarih Kültür ve Sanat Araştırmaları Dergisi, 3/1, 2014.

el-Mer'aşlî, Muhammed Abdurrahman, "Mukaddime", Envâru't-tenzîl ve esrâru't-te'vîl, nşr. Muhammed Abdurrahman el-Mer'aşlî, Beyrût, Dâru ihyâi'tturâsi'l-Arabî-Müessestu't-târîhi'l-Arabî, ts.

el-Merğinânî, Burhanuddin Ebu'l-Hasan Ali b. Ebibekir, el-Hidâye şerhu bidâyeti'l-mübteî maa şerhi Abdilhayy el-Leknevî, nşr. Nuaym Eşref Nûr Ahmed, Pakistan, İdâretu'l-Kur'ân ve'l-ulûmi'l-İslâmiyye, 1417.

Mevla el-Hasen b. el-Hüseyin b. el-Hayyân, “Ahkâmu'l-Kur'ân İlmi: Doğuşu, Gelişimi ve Eserleri Üzerine Bir Araştırma”, trc. Mustafa Şentürk-Mine Özer-Narin Yavuz, İslam Hukuku Araştırmaları Dergisi, 22, 2013.

Mollaibrahimoğlu, Melek, "Koca Râgıb Mehmed Paşa ve Hâşiye 'Alâ Tefsiri'l-Kâdî el-Beydâvî Adlı Eserin Tahlîli”, (Yayımlanmamış Yüksek Lisans Tezi), İstanbul Üniversitesi, İstanbul, 2019. 
Muallim Naci, Osmanlı Şairleri, haz. Cemal Kurnaz, Ankara, Kültür Bakanlı̆̆ı Yayınları, 1986.

el-Muhâmî, Muhammed Ferid Bey, Târihu'd-devleti'l-Osmâniyye, thk. İhsan Hakk1i Beyruti Dâru'n-nefâis, 1981.

Mutlu, İbrahim, “Koca Ragıp Paşa Kütüphanesi 200 Yaşında”, Türk Kütüphaneciler Derneği Bülteni, 12/1-2, 1963.

en-Nesefî, Necmuddin Ömer b. Muhammed Ebû Hafs, Et-Teysîr fi't-tefsîr, thk. Mahir Edib Habbûş, İstanbul, Dâru'l-lübâb, 1440/2019.

Özel, H. Abdulkadir, “Koca Râgıb Mehmed Paşa’nın Munşe’ât ve Telhîsâtı”, (Yayımlanmamış Yüksek Lisans Tezi), Mimar Sinan Güzel Sanatlar Üniversitesi, İstanbul, 2014.

Öztürk, Mustafa, “Kur'an’ın Kur'an'la Tefsiri: Bir Mahiyet Soruşturması”, Çukurova Üniversitesi Ilahiyat Fakültesi Dergisi, 8/2, 2008.

Pakalın, Mehmet Zeki, Osmanlı Tarih Deyimleri ve Terimleri Sözlüğü, İstanbul, Milli Eğitim Basımevi, 1971.

Ragıp Paşa, Hâşiyetu Râgıb Paşa ala Tefsiri'l-Beydâvî, Râgıb Paşa, 70, 1a-564b. Süleymaniye Kütüphanesi.

es-Sekkâkî, Ebû Ya'kûb Yusuf b. Ebibekir Muhammed b. Ali, Miftâhu'l-ulum, nşr. Naim Zerzûr. 2. bs., Beyrût, Dâru'l-kutubi’-ilmiyye, 1407/1987.

Süreyya, Mehmed, Sicill-i Osmâni, haz. Nuri Akbayar, İstanbul, Tarih Vakfı Yurt Yayınları, 1996.

Şem ‘dânîzâde Süleyman Efendi, Mur'i’t-tevârîh, haz. M. Münir Aktepe, İstanbul, İstanbul Üniversitesi Edebiyat Fakültesi Yayınları, 1976.

Şeyhzâde, Muhammed b. Muslihuddin Mustafa el-Kocevî el-Hanefî, Hâşiyetu Muhyiddîn Şeyhzâde alâ tefsîri'l-Kâdî el-Beydâvî, nşr. Muhammed Abdulkadir Şâhîn, Beyrût, Dâru'l-kutubi'l-ilmiyye, 1419/1999.

et-Tehânevî, Muhammed A'lâ b. Ali b. Muhammed Hâmid el-Faruki, Keşşâfu ustılâhâti'l-funûn ve'l-ulûm, thk. Ali Dehrûc, Beyrut, Mektebe Lübnan, 1996.

Türk Edebiyatı Isimler Sözlüğ̈̈, "Beyhan Kesik Koca Rağıb Paşa”, Erişim: 24.10.2020. http://teis.yesevi.edu.tr/madde-detay/koca-ragib-pasa.

Uğur, Hakan, “Konya Yusufağa ve Bölge Yama Eserler Kütüphanesi’ndeki Başlıca Beydâvî Hâşiyeleri”, Osmanlı Toplumunda Kur'an Kültürü ve Tefsir Çalışmaları 1, ed. Bilal Gökkır-Necdet Yılmaz-Necmettin Gökkır-Ömer Kara-Muhammed Abay-Mustafa Karagöz, İstanbul, İlim Yayma Vakfı, 2011. 
Uzunçarş1lı, İsmail Hakkı, Osmanlı Tarihi, Ankara, Türk Tarih Kurumu Yayınları, 1988.

Yavuz, Yusuf Şevki, “İ'câzü'1-Kur'ân”, Türkiye Diyanet Vakfi İslam Ansiklopedisi, 21, İstanbul, Türkiye Diyanet Vakfı Yayınları, 2000.

Yorulmaz, Hüseyin, Koca Ragıb Paşa, Ankara, Kültür Bakanlığı Yayınları, 1998.

, "Koca Râgıb Paşa Dîvânı (Araştırma ve Metin)", (Yayımlanmamış Yüksek Lisans Tezi), İstanbul Üniversitesi, İstanbul, 1989.

ez-Zeccâc, Ebû İshak İbrahim b. es-Sirrî, Meâni 'l-Kur'ân ve i 'râbuhu, Beyrut, Âlemu'l-kutub, 1988.

ez-Zehebî, Muhammed Hüseyin, et-Tefsîr ve'l-müfessirûn, el-Kâhire, Mektebetu Vehbe, ts.

ez-Ziriklî, Ebû Gays Muhammed Hayruddîn b. Mahmud b. Muhammed Ali, el-A'lâm kâmûsu terâcimi eşheri'r-ricâli ve'n-nîsâi mine'l-arabî ve'l-musta'rabîn ve'l-musteşrikîn, 15. bs., Beyrut, Dâru'l-ilim li'l-melâyîn, 2002. 
